\title{
The Distribution of GABAergic Cells, Fibers, and Terminals in the Monkey Amygdaloid Complex: An Immunohistochemical and in situ Hybridization Study
}

\author{
A. Pitkänen ${ }^{1}$ and D. G. Amaral ${ }^{2}$ \\ 'University of Kuopio, Department of Neurology, SF-70211 Kuopio, Finland and ${ }^{2}$ The Salk Institute, Laboratory of Neuronal \\ Structure and Function, La Jolla, California 92037
}

The primate amygdaloid complex is a prominent structure in the medial temporal lobe that comprises a variety of cytoarchitectonically distinct nuclei and cortical regions. The present study employed immunohistochemical and in situ hybridization techniques to determine the distribution of GABAergic cells, fibers, and terminals in the macaque monkey amygdala. Using a monoclonal antibody to GABA, immunoreactive neurons were observed throughout the amygdaloid complex (constituting approximately $20 \%$ of the neurons in the lateral nucleus), with higher densities located in the intercalated nuclei, amygdalohippocampal area, and posterior cortical nucleus. The lowest densities of labeled cells were observed in the central and medial nuclei. Interestingly, despite the low number of GABA-immunoreactive neurons, the terminal density in the central nucleus was among the highest in the amygdala. The GABAergic neurons in the amygdala were heterogeneous in morphology, and three general classes of immunopositive aspiny cells were observed. Using mRNA probes for glutamic acid decarboxylase (GAD: $G_{A D}$ and $G_{6 A}$ ), in situ hybridization demonstrated distributions of labeled cells that generally replicated the immunohistochemical findings. One exception was in the central nucleus where, in contrast to the low number of immunohistochemically labeled cells, both GAD probes labeled large numbers of neurons. These studies on the organization of GABAergic circuits in the primate amygdala are significant because alterations of function in the human amygdala have been implicated in the pathogenesis of temporal lobe epilepsy and in the etiology of affective and other behavioral disorders. The present study provides baseline information with which to evaluate the role of GABAergic systems in amygdala-mediated behaviors and the potential

\footnotetext{
Received May 13, 1993; revised Sept. 9, 1993; accepted Sept. 29, 1993.

This work was supported by NIMH Grant MH41479 (to D.G.A.), by a Fogarty International Fellowship (1 F05 TW04343), and by the Academy of Finland, Medical Council (to A.P.). This work was also conducted, in part, at the California Regional Primate Center in Davis, CA (NIH Grant RR00169). We thank Dr. Ismo Virtanen for kindly providing the antibody to GABA (115AD5) used in these studies and Dr. Alan Tobin for permission to use the $\mathrm{GAD}_{65}$ and $\mathrm{GAD}_{6}$ probes. We also thank Dr. Paul E. Sawchenko and Carlos Arias for their help in conducting the in situ portion of the study, Kaon Tong for histological assistance Kris Trulock for photugraphic processing, and Belle Wamsley for secretarial assistance.

Correspondence should be addressed to Dr. David G. Amaral, Center for Behavioral Neuroscience, SUNY at Stony Brook, Stony Brook, NY 11794-2575. Copyright (C) 1994 Society for Neuroscience $0270-6474 / 94 / 142200-25 \$ 05.00 / 0$
}

contribution of GABAergic dysfunction in amygdala-associated disorders.

IKey words: GABA, amygdala, epilepsy, glutamic acid decarboxylase, inhibitory amino acid, interneuron, primate]

The monkey amygdaloid complex is a cytoarchitectonically heterogeneous structure that is composed of at least 13 different nuclei and cortical areas, many of which are subdivided into two or more regions. While there is increasing evidence for substantial heterogeneity in the connectivity and chemoanatomy of the amygdaloid complex (Amaral et al., 1992), understanding of the intra- and internuclear organization of connections in the amygdala has lagged behind the detailed information available for the neocortex or other medial temporal lobe regions, such as the hippocampal formation. In particular, there has only been meager histological analysis of the organization of GABAergic circuitry in the primate amygdaloid complex.

The lack of information on GABAergic mechanisms in the primate amygdala is particularly troubling since there is mounting evidence that the amygdaloid complex is involved in the pathogenesis of temporal lobe epilepsy (Margerison and Corsellis, 1966; Bruton, 1988; Hudson et al., 1991; Watson et al., 1991; Hudson, 1993). Moreover, the amygdala plays a prominent role in various experimental animal models of epilepsy, such as kindling. As initially demonstrated by Goddard et al. (1969), the amygdala is one of only a few forebrain sites in which stimulation is particularly effective in producing kindled seizures. Germane to the present study, there is suggestive evidence that alterations in GABAergic inhibitory mechanisms in the amygdala may contribute to the establishment of kindlinginduced seizures (Löscher and Schwark, 1987; Kamphuis and Lopes da Silva, 1990; Callahan et al., 1991; Rainnie et al., 1992).

A number of lines of evidence indicate that the amygdala normally plays a role in the mediation of species-specific and emotional behaviors (Le Doux, 1987, 1992; Davis, 1992). Consistent with this notion, both experimental animal and human clinical studies have demonstrated that pathology of the amygdala is associated with psychoaffective behavioral disorders (Weiskrantz, 1956; Aggleton and Passingham, 1981; Tranel and Hyman, 1990; Zola-Morgan et al., 1991 ; Drevets et al., 1992). In this regard, it is interesting that the amygdala has one of the highest concentrations of benzodiazepine/GABA $\mathrm{A}_{\mathrm{A}}$ receptors (Niehoff and Kuhar, 1983; Niehoff and Whitehouse, 1983; Marcel et al., 1986; Zezula et al., 1988; Stroessner et al., 1989) and at least some of the anxiolytic effects of the benzodiazepines may be mediated by the amygdala. Thus, it would be of sub- 
stantial importance to determine the cellular organization of the GABAergic system in the primate amygdaloid complex.

The rat amygdala demonstrates a large number of neurons immunoreactive for GABA (McDonald, 1985; Ottersen et al., 1986; Nitecka and Ben-Ari, 1987) or glutamic acid decarboxylase (GAD) (Mugnaini and Oertel, 1985; Carlsen, 1988; Nitecka and Frotscher, 1989). The highest numbers of GABAimmunoreactive (-ir) and GAD-ir cell bodies are located in the lateral, basal (or basolateral nucleus as it is often called in the rat) and accessory basal (or basomedial) nuclei. In contrast to the cellular distribution, GABA-ir and GAD-ir terminal labeling is denser in the central and medial nuclei than in the deep nuclei. Neurochemical analyses of GABA distribution are largely consistent with the histological data (Ben-Ari et al., 1976; Nakamura et al., 1987). Lesion studies carried out in rat indicate that most of the GABA in the amygdala, especially in the lateral and basal nuclei, is of intrinsic origin, though some $25 \%$ of the GAD in the central nucleus may be contributed by afferent projections (Le Gal La Salle et al., 1978).

Despite the potential importance of understanding the organization of inhibitory mechanisms in the primate medial temporal lobe, there is little published information on the distribution of GABAergic neurons in the primate amygdaloid complex (McDonald and Augustine, 1993). Thus, in the present study, two approaches were taken to investigate the organization of GABAergic cells, fibers, and terminals in the monkey amygdala. First, the distribution of GABA-ir cells and terminals was mapped using a monoclonal antibody raised against GABABSA complex (Szabat et al., 1992). Second, in situ hybridization of mRNAs for the two molecular forms of GAD [65 kDa GAD $\left(\mathrm{GAD}_{65}\right)$ and $\left.67 \mathrm{kDa} \mathrm{GAD}\left(\mathrm{GAD}_{67}\right)\right]$ was used to study the distribution of expression of the GABA synthetic enzyme, GAD, throughout the amygdala.

\section{Materials and Methods}

\section{Animals and fixatives}

GABA immunohistochemistry. The brains of three Macaca fascicularis monkeys (M17-91, M18-91, M19-91) were prepared for the immunohistochemical demonstration of GABA. Two monkeys were perfused intracardially with a fixative containing a low concentration of glutaraldehyde, and one was perfused with a fixative containing a higher concentration of glutaraldehyde. In all cases, animals were deeply anesthetized with ketamine $\mathrm{HCl}(10 \mathrm{mg} / \mathrm{kg}, \mathrm{i} . \mathrm{m}$.) followed by sodium pentobarbital $(50 \mathrm{mg} / \mathrm{kg}$, i.p.). For the low-glutaraldehyde fuxation, animals were perfused with $0.9 \%$ sodium chloride $(250 \mathrm{ml} / \mathrm{min}$, for $2 \mathrm{~min})$ followed by a solution of $0.1 \%$ glutaraldehyde and $4 \%$ paraformaldehyde in $0.1 \mathrm{M}$ sodium phosphate buffer, $\mathrm{pH} 7.4(250 \mathrm{ml} / \mathrm{min}$ for $10 \mathrm{~min} ; 100$ $\mathrm{ml} / \mathrm{min}$ for $50 \mathrm{~min}$ ). In the high-glutaraldehyde fixation protocol, a solution of $2.5 \%$ glutaraldehyde and $1 \%$ paraformaldehyde in $0.1 \mathrm{~m}$ sodium phosphate buffer, pH $7.4(250 \mathrm{ml} / \mathrm{min}$ for $10 \mathrm{~min} ; 100 \mathrm{ml} / \mathrm{min}$ for $50 \mathrm{~min}$ ), was used as the fixative. The brains were blocked stereotaxically and postfixed in the perfusion fixative for $6 \mathrm{hr}$. The brains were cryoprotected with $10 \%$ and then $20 \%$ glycerol with $2 \%$ dimethyl sulfoxide, frozen, cut, and stored (in 30\% ethylene glycol, $25 \%$ glycerol in $0.05 \mathrm{M}$ sodium phosphate buffer, $\mathrm{pH} 7.4$ ) as described previously (Pitkänen and Amaral, 1993a).

$G A D$ in situ hybridization. The brains of two Macaca fascicularis monkeys (M3-91 and M5-91) were prepared for the demonstration of mRNAs that code two forms of GAD, $65 \mathrm{kDa}$ GAD $\left(\mathrm{GAD}_{65}\right)$ and 67 $\mathrm{kDa} G A D\left(\mathrm{GAD}_{67}\right)$. The monkeys were perfused intracardially by using a pH-shift fixation protocol (Berod et al., 1981) as previously described (Pitkänen and Amaral, 1991).

\section{Immunohistochemical procedures}

Sections from two of the brains (M17-91 and M18-91) were stained by the peroxidase-antiperoxidase (PAP) method and sections from the third brain (M19-91) were stained by the avidin-biotin technique.
PAP method. Whole, free-floating coronal sections were collected from the cryoprotectant solution and washed three times in $0.02 \mathrm{M}$ potassium phosphate buffer, $\mathrm{pH} 7.4$ (KPBS), and incubated in a blocking solution containing $10 \%$ normal rabbit serum and $0.5 \%$ Triton X-100 in KPBS for $4 \mathrm{hr}$ at room temperature. The sections were then incubated in a solution that contained a monoclonal mouse anti-GABA antibody (115AD5, kindly provided by Dr. Ismo Virtanen, Department of Anatomy, University of Helsinki, Helsinki, Finland) (Szabat et al., 1992) diluted $1: 30,0.5 \%$ Triton X-100, and 1\% normal rabbit serum in KPBS for $48 \mathrm{hr}$ at $4^{\circ} \mathrm{C}$. The sections were then washed in KPBS (pH 7.4) and incubated in a solution containing rabbit anti-mouse IgG (1:30) (ICN $65-157), 1 \%$ normal rabbit serum, and $0.2 \%$ Triton X-100 in KPBS, (pH 7.4) for $4 \mathrm{hr}$ at room temperature. The sections were again washed and then incubated overnight at $4^{\circ} \mathrm{C}$ in a solution that contained mouse PAP (1:100) (Sternberger Monoclonals, \#405), 1\% normal rabbit serum, and $0.2 \%$ Triton X-100 in KPBS, $\mathrm{pH} 7.4$. After further washing, the sections were reacted with diaminobenzidine (DAB) (Pierce, \#34001) $\left(0.05 \%\right.$ DAB and $0.04 \% \mathrm{H}_{2} \mathrm{O}_{2}$ in KPBS, pH 7.4). The sections were rinsed, mounted on gelatin-coated slides, and intensified with $\mathrm{OsO}_{4}$ and thiocarbohydrazide by the method of Lewis et al. (1986) or with the silver intensification method described by Quinn and Graybiel (1990).

Avidin-biotin method. In this method the sections were incubated for $2 \mathrm{~d}$ in mouse monoclonal anti-GABA antiserum (diluted 1:400). The incubation protocol followed the same procedure described previously for the identification of parvalbumin-ir cells (Pitkänen and Amaral, 1993a).

Characterization of antibody and controls for specificity. The characterization of the GABA antibody used in these studies has been described in detail (Szabat et al., 1992). Three controls for specificity were used. First, control sections were incubated without the primary antibody; this resulted in the complete disappearance of stained profiles. Second, the primary antibody (dilution 1:30) was incubated overnight with different concentrations of GABA (Sigma, \#A-2129) ranging from $1 \mu \mathrm{M}$ to $1 \mathrm{M}$. Monkey sections were then added to each mixture and processed as described above. The addition of $1 \mathrm{~mm}$ GABA to the incubation solution resulted in a marked loss of immunoreactivity while the addition of $1 \mathrm{~m}$ GABA eliminated immunostained profiles. As an additional control, we compared the distribution of stained cells obtained with preparations using monoclonal antibody 115AD5 to that obtained with preparations stained using a commercially available polyclonal antibody (Sigma antibody \#A-2052). The overall distribution of cells in the two preparations was very similar though dendritic labeling was substantially more extensive with antibody 115AD5.

\section{In situ hybridization}

cRNA probe synthesis. ${ }^{35} \mathrm{~S}$-radiolabeled antisense and sense cRNAs were transcribed from two GAD cDNA clones inserted into Bluescript M13+ SK vectors (kindly provided by Dr. Alan Tobin, UCLA) (Erlander et al., 1991). The synthesis of radiolabeled cRNA probes was based on the transcription protocol provided with the Riboprobe Gemini System IV kit (Promega). The $\mathrm{GAD}_{65}$ probe was 2.01-kilobase (kb)-long human $\mathrm{GAD}_{65}$ isolated from a $\lambda$-zap II human hippocampal library obtained from Stratagene; the $\mathrm{GAD}_{67}$ probe fao $2.7 \mathrm{~kb}$ human $\mathrm{GAD}_{67}$ isolated from a $\lambda$ gt-11 human fetal brain library, which was inserted into the EcoRI site of the Bluescript M13 + SK vector (Stratagene). The labeled probes $\left(10^{7} \mathrm{cpm} / \mathrm{ml}\right)$ were mixed in hybridization solution containing $0.5 \mathrm{mg} / \mathrm{ml}$ tRNA, $10 \mathrm{~mm}$ dithiothreitol (DTT), $50 \%$ formamide, 0.25 $\mathrm{M} \mathrm{NaCl}, 1 \mathrm{~mm}$ EDTA, and $1 \times$ Denhardt's solution.

In situ hybridization. Sections were collected from cryoprotectant solution, washed three times in $0.02 \mathrm{M} \mathrm{KPBS}$, and put into $10 \%$ buffered formalin overnight. The sections were washed twice in KPBS and mounted on gelatin/poly-L-lysine-coated slides. Sections were pretreated with $0.001 \%$ proteinase $\mathrm{K}$ in $0.1 \mathrm{M}$ Tris buffer ( $\mathrm{pH} 8.0$ ), containing $0.05 \mathrm{M}$ EDTA for $30 \mathrm{~min}$ at $37^{\circ} \mathrm{C}$. Thereafter, sections were briefly washed in deionized water, rinsed in $0.1 \mathrm{M}$ triethanolamine (TEA) at $\mathrm{pH} 8.0$, and acetylated $(0.625 \mathrm{ml}$ of acetic anhydride, $250 \mathrm{ml}$ of $0.1 \mathrm{M}$ TEA, pH 8.0). Sections were rinsed in $2 \times \mathrm{SSC}(1 \times \mathrm{SSC}$ is $0.15 \mathrm{M}$ saline, $0.015 \mathrm{M}$ sodium citrate), dehydrated in ascending ethanol series, and dried with desiccant under vacuum at room temperature until hybridization was initiated. Hybridization solution $(100 \mu \mathrm{l})$ containing 10 $\mathrm{cpm} / \mathrm{ml}$ of cRNA probe was spotted on each slide, coverslipped, and sealed with DPX. Slides were placed on a slide warmer at $60^{\circ} \mathrm{C}$ overnight. Following hybridization, sections were rinsed in $4 \times \mathrm{SSC}$ and treated with $20 \mu \mathrm{g} / \mathrm{ml}$ ribonuclease $A$ for $30 \mathrm{~min}$ at $37^{\circ} \mathrm{C}$. Thereafter, 
sections were washed in decreasing concentrations of SSC containing 1 mM DTT to a final high-stringency wash in $0.1 \times \mathrm{SSC}$ at $70^{\circ} \mathrm{C}$ for 30 $\mathrm{min}$. Sections were dehydrated in increasing ethanol concentrations and dried.

Hybridized sections were exposed to Amersham $\beta$ Max Hyperfilm for $2 \mathrm{~d}$. Following this, sections were defatted in xylene, dried, dipped in Kodak NTB-2 emulsion, and exposed for $8 \mathrm{~d}$. After developing, sections were counterstained with thionin. The pattern of labeled cells was identical in the two brains studied for each probe. The control sections hybridized with sense probes did not show any cellular labeling.

\section{Analysis}

All sections were analyzed with a Leitz Dialux 20 microscope with both bright-field and dark-field optical systems. The distribution of GABAir cell bodies in a representative series of coronal sections from one of the cases was plotted using a computer-aided digitizing system (Minnesota Datametrics). Camera lucida drawings from adjacent Nissl-stained sections were uscd to define the various nuclei of the amygdala and the outline and plots were superimposed using the CANVAS 3.04 software package on a Macintosh computer. Cell counts and measures of cell density (cells $/ \mathrm{mm}^{2}$ ) were obtained from these plots. In order to get a rough estimate of the proportion of GABAergic cells in the amygdala, we plotted the distribution of Nissl-stained cells in the lateral nucleus from one section adjacent to a section plotted for the distribution of GABA-positive cells. While the numbers generated by the counts of GABA-ir neurons are clearly only approximations to the actual number of GABAergic cells in the lateral nucleus, the counts were apparently not affected by some common technical limitations. Penetration of the GABA antibody, for example, appeared to be fairly uniform through the $30 \mu \mathrm{m}$ sections and thus most of the GABAergic neurons were apparently identified by the immunohistochemical procedure. Similarly, quantitative comparisons of the present results with the findings of previous studies on the distribution of parvalbumin- and calbindinimmunoreactive cells should also be regarded as tentative. The necessity of using fixatives for the GABA preparations that differed from those used for the calcium-binding protein studies makes the comparison of shape and size of neurons across preparations somewhat problematic. Comparisons of the number of labeled cells in different preparations should not be affected by differences in fixation and thus these findings might be regarded as more robust. The distribution of $\mathrm{GAD}_{65}-$ and $\mathrm{GAD}_{67}$-labeled cells in the in situ hybridization preparations from case M5-91 were also plotted as described above.

It was clear at early stages of the analysis that the GABA-positive cells formed a heterogeneous neuronal population. To aid in the description of these cells, we measured the cross-sectional areas of a sample of cells $(n=1297)$ from a representative section of the lateral nucleus (cells were measured from the section illustrated in Fig. $2 C$ ). Cells were drawn using a microscopic drawing tube and a $100 \times$ objective (total magnification, $1380 \times$ ). The area of each cellular profile was determined using a digitizing tablet and sIGMASCAN software. Statistical analysis was carried out with the STATVIEW statistical package.

Low-power dark-field and bright-field photomicrographs were taken with a Nikon Multiphot $4 \times 5$ inch system. Higher-magnification photomicrographs were taken with a Leitz Dialux 20 microscope equipped with a Wild MPS camera system. Additional photomicrographs were taken with Nomarski optics.

\section{Results}

Nomenclature of amygdaloid nuclei and cortical areas

We have previously provided detailed descriptions of the nomenclature used for the amygdaloid complex (Price et al., 1987; Amaral et al., 1992). The various amygdaloid areas are indicated in the GABA-ir section illustrated in Figure 1 and in the Nisslstained sections in Figure 2. Briefly, the deep nuclei include the lateral nucleus (subdivided into ventrolateral and dorsomedial divisions), the basal nucleus (subdivided into magnocellular, intermediate, and parvicellular divisions), the accessory basal nucleus (partitioned into magnocellular, parvicellular, and ventromedial divisions), and the paralaminar nucleus. The superficial areas include the anterior cortical nucleus, the medial nucleus, the nucleus of the lateral olfactory tract, the periamyg- daloid cortex (which can be subdivided into at least three subregions: PACs, PAC2, and PAC3), and the posterior cortical nucleus. The remaining areas consist of the anterior amygdaloid area, the central nucleus (divided into lateral and medial subdivisions), the amygdalohippocampal area (which has dorsal and ventral subdivisions), and the intercalated nuclei.

\section{General characteristics of GABA immunoreactivity}

GABA immunoreactivity was only associated with neuronal cell bodies and axonal and dendritic processes. In addition to labeling of the soma and dendrites (Figs. 3, 4) short, initial portions of the axon were occasionally labeled (Fig. 3, cells 5 and 8 ). In brains perfused with the fixative containing the low concentration of glutaraldehyde, diffuse GABA immunoreactivity was seen throughout the soma and dendritic tree. In the brain fixed with the higher concentration of glutaraldehyde, the reaction product tended to have a more granular appearance and dendrites were not labeled. Neuropil staining consisted of varicose fibers and diffusely distributed varicosities. The neuropil staining was denser in the material fixed with the higher concentration of glutaraldehyde (Fig. $5 A, B$; see Fig. $8 B$ ).

\section{Types of GABA-ir amygdaloid neurons}

Three morphologically distinct types of GABA-ir neurons were observed in the monkey amygdala (Figs. 3, 4). All were aspiny and resembled neurons immunoreactive for the calcium-binding proteins parvalbumin (Pitkänen and Amaral, 1993a) and calbindin- $\mathrm{D}_{28 \mathrm{k}}$ (Pitkänen and Amaral, 1993b).

Type 1 cells were the most numerous $\mathrm{GAB} \Lambda$-ir neurons. They were small, multipolar cells found throughout the amygdala (Fig. 3, cells 1-7; Fig. 4A-C; see Table 2). Two subtypes of type 1 cells were observed: most cells were stellate with 8-12 thin, beaded primary dendrites (Fig. 3, cells 1-4; Fig. 4A). The second subtype was multipolar with fewer and thicker primary dendrites. The primary dendrites began to branch approximately $15-20 \mu \mathrm{m}$ away from the cell body and generated a beaded distal dendritic tree (Fig. 3, cells 5-7).

Type 2 cells were larger than type 1 cells, were multipolar, had at least one prominent dendrite emanating from the soma (Fig. 3, cells 8-1 1; Fig. 4D,E; see Table 2) and were most commonly found in the deep nuclei. Type 2 cells could also be divided into two subtypes. The first subtype had relatively short primary dendrites that gave off beaded secondary and more distal dendrites (Fig. 3, cells 10-11). The second subtype tended to be somewhat larger than the first and had thicker dendrites with large, flattened varicosities (Fig. 3, cells 8 and 9).

Type 3 GABA-positive cells had a fusiform shape and were relatively rare (Fig. 3 , cell 12 ; Fig. $4 F$; see Table 2 ). The few type 3 cells were typically found in the deep nuclei.

\section{Appearance of GABA-ir fibers and terminals}

The density of GABA-ir ncuropil in the monkey amygdala ranged from relatively low to very high. Neuropil staining was particularly high in the central nucleus and in the superficial nuclei (see Figs. 1, 8; Table 1). As noted above, these regions had relatively few GABA-ir cell bodies (compare Figs. $2 D^{\prime}, 8 B$ ). The deep nuclei demonstrated a lower level of neuropil staining (see Figs. 1, 8).

Neuropil staining often contained pericellular basket-like plexuses that were generally observed around unstained cell bodies (Fig. $5 A, B$ ). These profiles were more numerous in the deep nuclei and in the periamygdaloid cortex. In a previous 


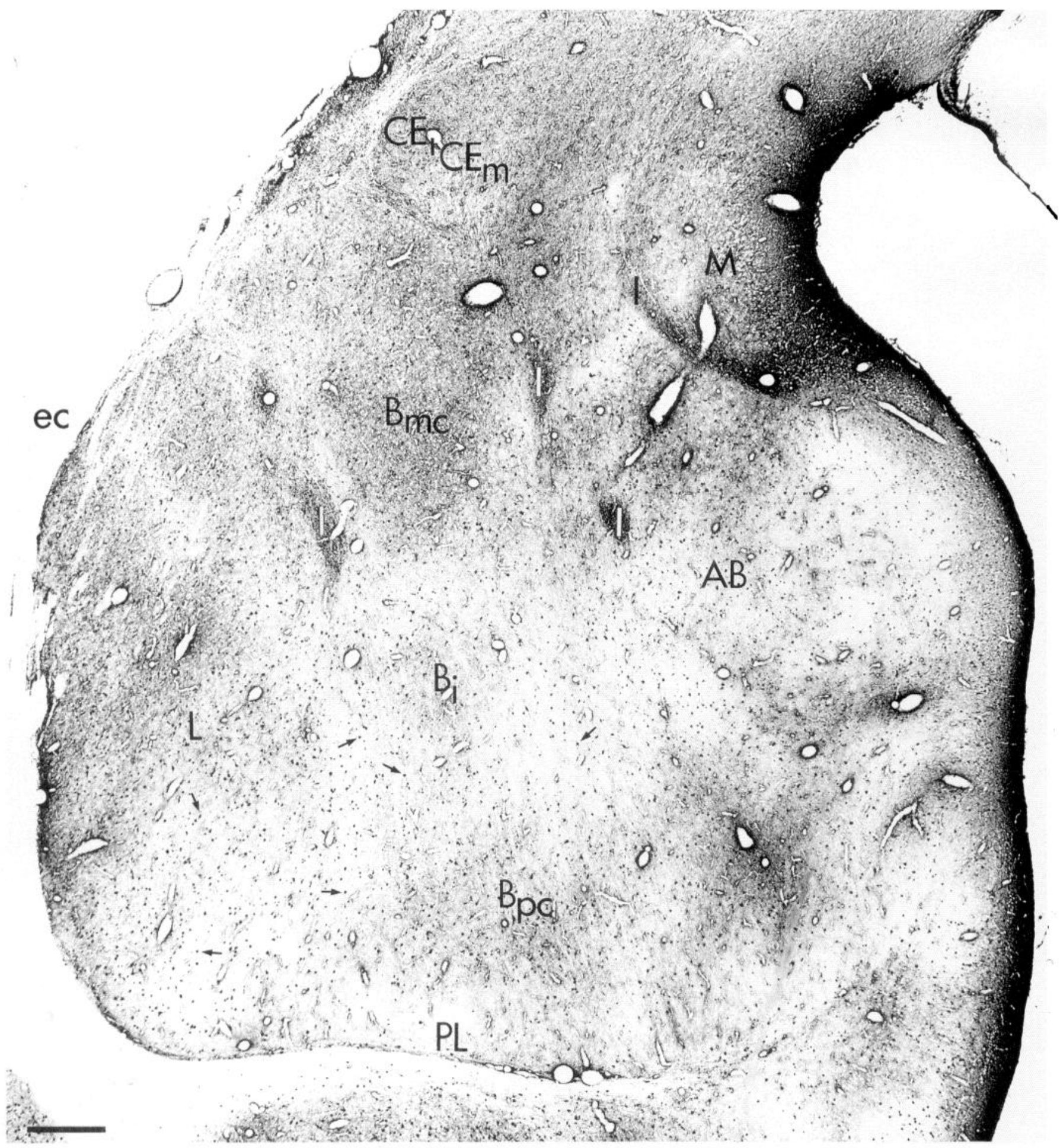

Figure 1. Bright-field photomicrograph of a coronal section through a mid-rostrocaudal level of the monkey amygdaloid complex illustrating the overall distribution of GABA immunoreactivity. Numerous black dots (arrows) throughout the section are GABA-ir neuronal cell bodies. Note the darkly stained intercalated nuclei $(I)$ that contain numerous labeled cells and dense immunoreactive fiber and terminal plexuses. The section photographed in this figure was intensified by the gold chloride method and thus has an overall different appearance from the section photographed in Figure 8, which was processed with $\mathrm{O}_{\mathrm{s}} \mathrm{O}_{4}$ intensification. $A B$, accessory basal nucleus; $B_{i}$, basal nucleus (intermediate subdivision); $B_{m c}$, basal nucleus (magnocellular subdivision); $B_{p c}$, basal nucleus (parvicellular subdivision); $C E_{l}$, central nucleus (lateral subdivision); $C E_{m}$, central nucleus (medial subdivision); $e c$, external capsule; $L$, lateral nucleus; $M$, medial nucleus; $P L$, paralaminar nucleus. Scale bar, $0.5 \mathrm{~mm}$. 

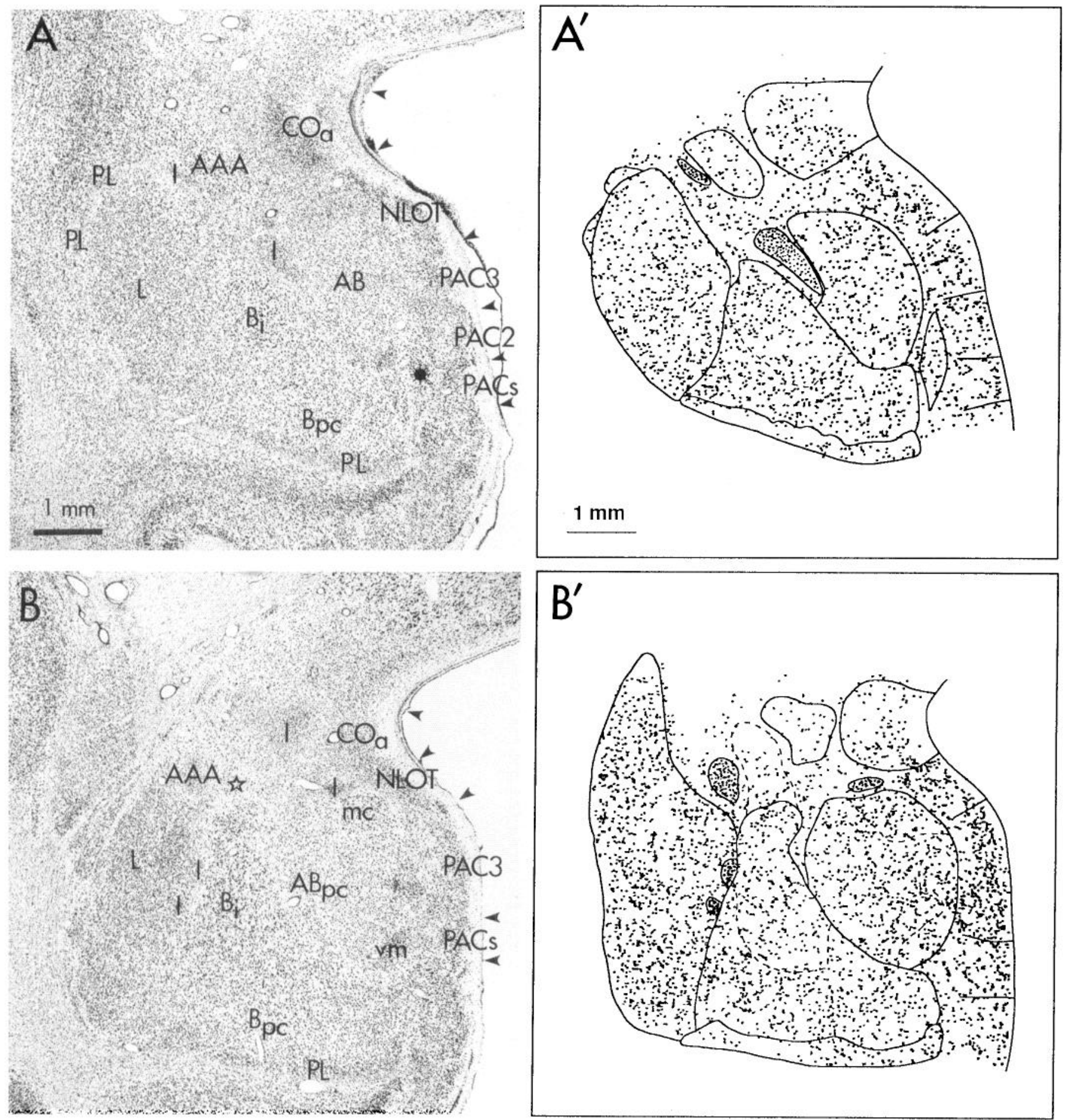

Figure 2. Distribution of GABA-ir neurons in the various nuclei and cortical regions of the monkey amygdala. $A-D$ are Nissl-stained sections from four rostrocaudal levels of the amygdala [(arranged from rostral $(A)$ to caudal $(D)]$ that indicate the location of different amygdaloid nuclei and cortical areas. $A^{\prime}-D^{\prime}$ are computer-generated plots of the locations of GABA-ir cells digitized from sections adjacent to the ones in $A-D$. Each dot represents one GABA-ir neuron. Asterisk-shaped symbol in $A$ indicates the location of the "triangular nucleus" described originally by Amaral and Bassett (1989). The star in $B$ indicates the beginning of the magnocellular division of the basal nucleus. Snowflake in $C$ indicates the transition area between the nucleus of the lateral olfactory tract and the posterior cortical nucleus. Arrowheads indicate boundaries between superficial regions. $A A A$, anterior amygdaloid area; $A B$, accessory basal nucleus; $A B_{p c}$, accessory basal nucleus (parvicellular subdivision); $A H A$, amygdalahippocampal area; $B$, basal nucleus; $B_{i}$, basal nucleus (intermediate subdivision); $B_{m c}$, basal nucleus (magnocellular subdivision); $B_{p c}$, basal nucleus (parvicellular subdivision); $C E_{l}$, central nucleus (lateral subdivision); $C E_{m}$, central nucleus (medial subdivision); $C O_{a}$, anterior cortical nucleus; $C O_{p}$, posterior cortical nucleus; $I$, intercalated nucleus; $L$, lateral nucleus; $M$, medial nucleus; $m c$, accessory basal nucleus (magnocellular subdivision); $N L O T$, nucleus of the lateral olfactory tract; $P A C 2, P A C 3$, and $P A C s$, subdivisions of the periamygdaloid cortex; $P L$, paralaminar nucleus; $P U$, putamen; $v m$, accessory basal nucleus (ventromedial subdivision). Scale bars $(A, A), 1 \mathrm{~mm}$ for all panels. 

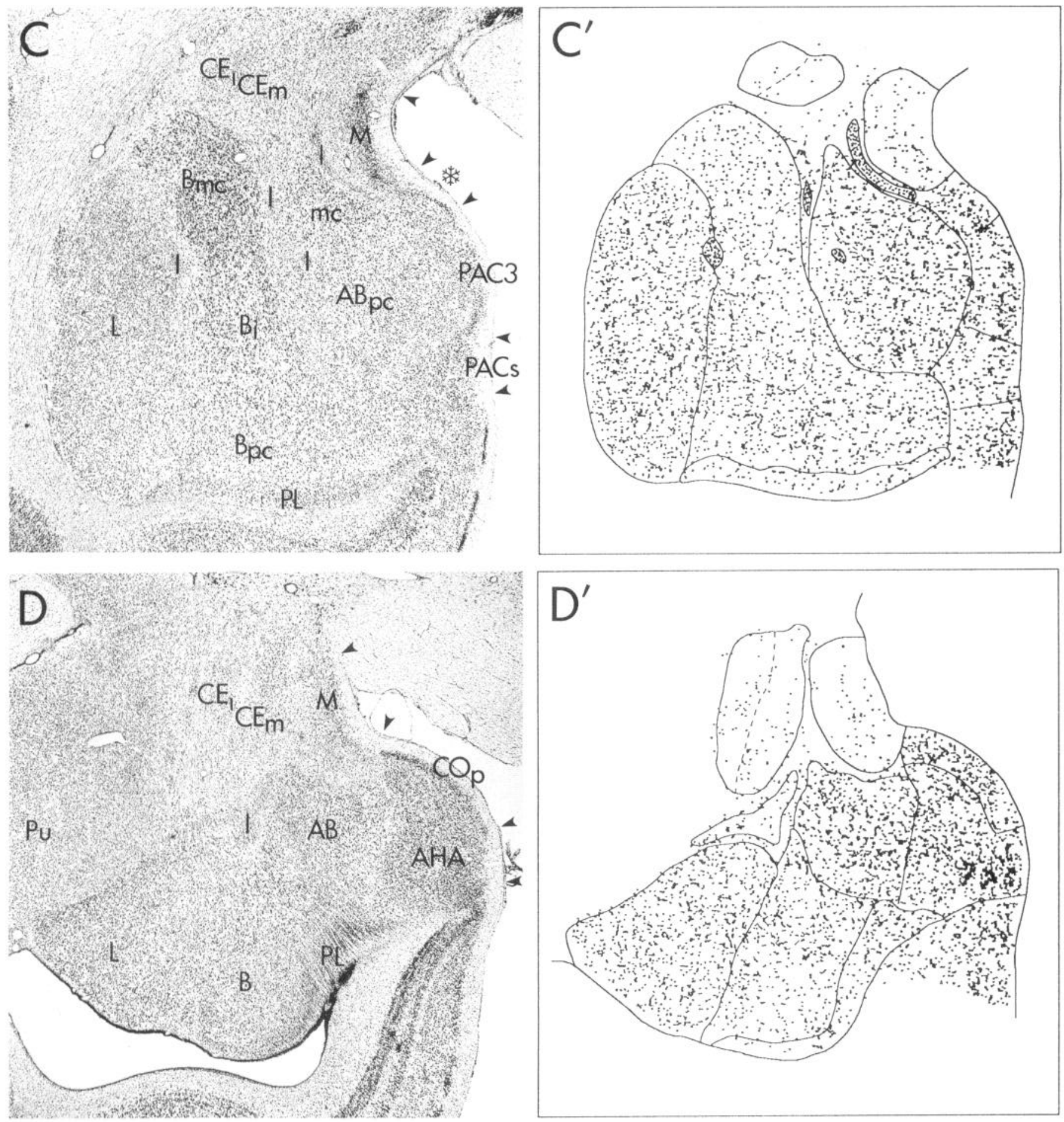

Figure 2. Continued.

analysis of parvalbumin immunoreactivity in the monkey amygdala, linear terminal profiles reminiscent of axoaxonic cartridges were commonly observed in the basal and lateral nuclei (Pitkänen and Amaral, 1993a); these profiles were rarely detected in the GABA preparations.

General appearance and distribution of cells demonstrating $\mathrm{GAD}_{65}$ or $\mathrm{GAD}_{67}$ mRNA

The in situ hybridization preparations yielded clear-cut cellular labeling (Figs. 6, 7, 9, 10) and there was generally a close cor-

respondence between the distribution and density of GABA-ir cells and cells that demonstrated GAD mRNAs. The number of cells containing $\mathrm{GAD}_{65}$ mRNA in the various amygdaloid nuclei was highly correlated with the number containing $\mathrm{GAD}_{67}$ mRNA $\left(r^{2}=0.895\right)$. The density of cells positive for GABA, $\mathrm{GAD}_{65}$ mRNA, or $\mathrm{GAD}_{67} \mathrm{mRNA}$ in each of the amygdaloid nuclei is illustrated in Figure $11 C$. It is obvious from this illustration that there is a lack of correspondence between the immunohistochemical and in situ hybridization preparations in the central, medial, and anterior cortical nuclei. In all three 


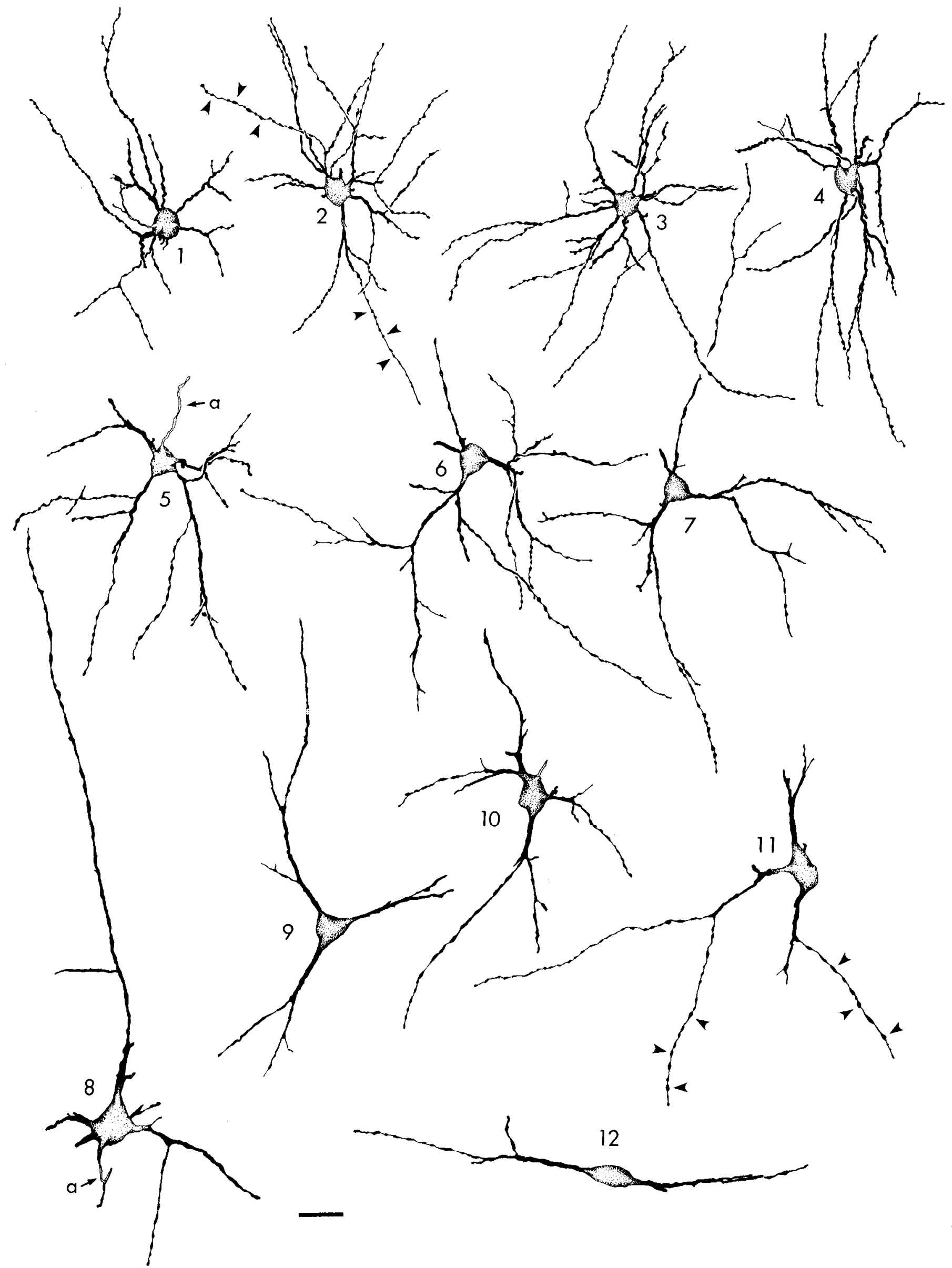

Figure 3. Camera lucida drawings of neurons immunoreactive for GABA in the monkey amygdala. Neurons $1-7$ are examples of type 1 cells, neurons $8-11$ are type 2 cells, and neuron 12 is a type 3 cell. Arrowheads pointing at cells 2 and 11 indicate the beaded appearance of dendrites. The initial segment of axons are indicated by $a$ in cells 5 and 8 . Scale bar, $20 \mu \mathrm{m}$. 

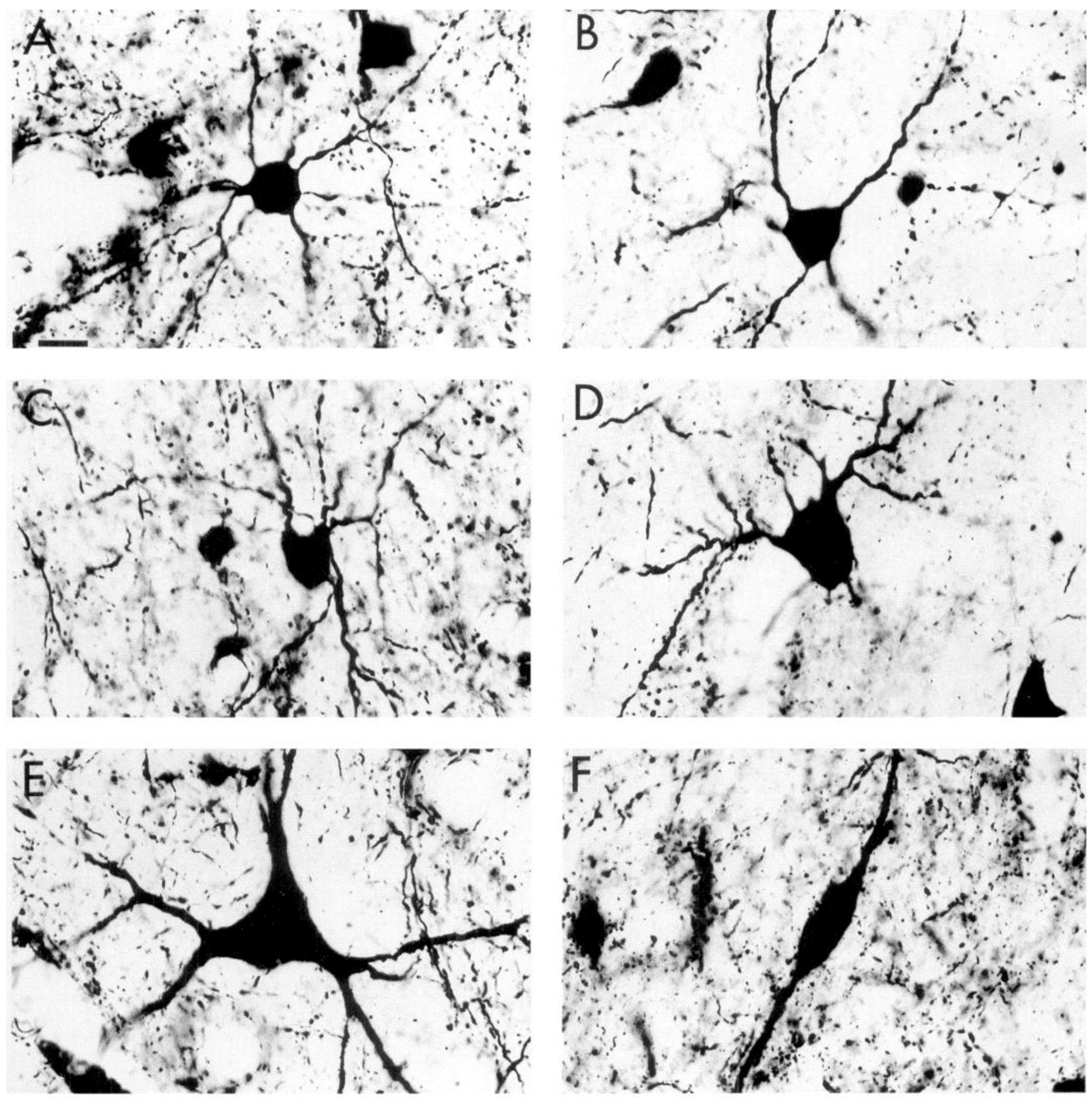

Figure 4. Bright-field photomicrographs of GABA-ir neurons in the monkey amygdala. $A-C$ represent type 1 cells $(A$ from the lateral nucleus; $B$ and $C$ from the parvicellular division of the basal nucleus). $D$ and $E$ show examples of type 2 cells (both neurons are from the parvicellular division of the basal nucleus); $F$ illustrates a type 3 neuron (from the lateral nucleus). Scale bar, $10 \mu \mathrm{m}$.

nuclei, the density of GABA-ir cells was very low compared to the number of cells positive for $\mathrm{GAD}_{65}$ and $\mathrm{GAD}_{67}$ mRNA (Figs. $2,6)$.

Distribution of GABA immunoreactivity and $\mathrm{GAD}_{65}$ - or $\mathrm{GAD}_{67}$-labeled cells in the various nuclei and cortical regions of the monkey amygdala

In the following, we will summarize the major features of the immunohistochemical and in situ staining patterns for each of the nuclei of the amygdaloid complex starting with the deep nuclei, moving on to the superficial regions, and then concluding with other amygdaloid areas such as the central nucleus.

\section{Deep nuclei}

Lateral nucleus

Among the deep nuclei, the lateral nucleus had the highest density of GABA-positive cells (Fig. 11C). GABA-ir cells were distributed throughout the lateral nucleus and there was no 


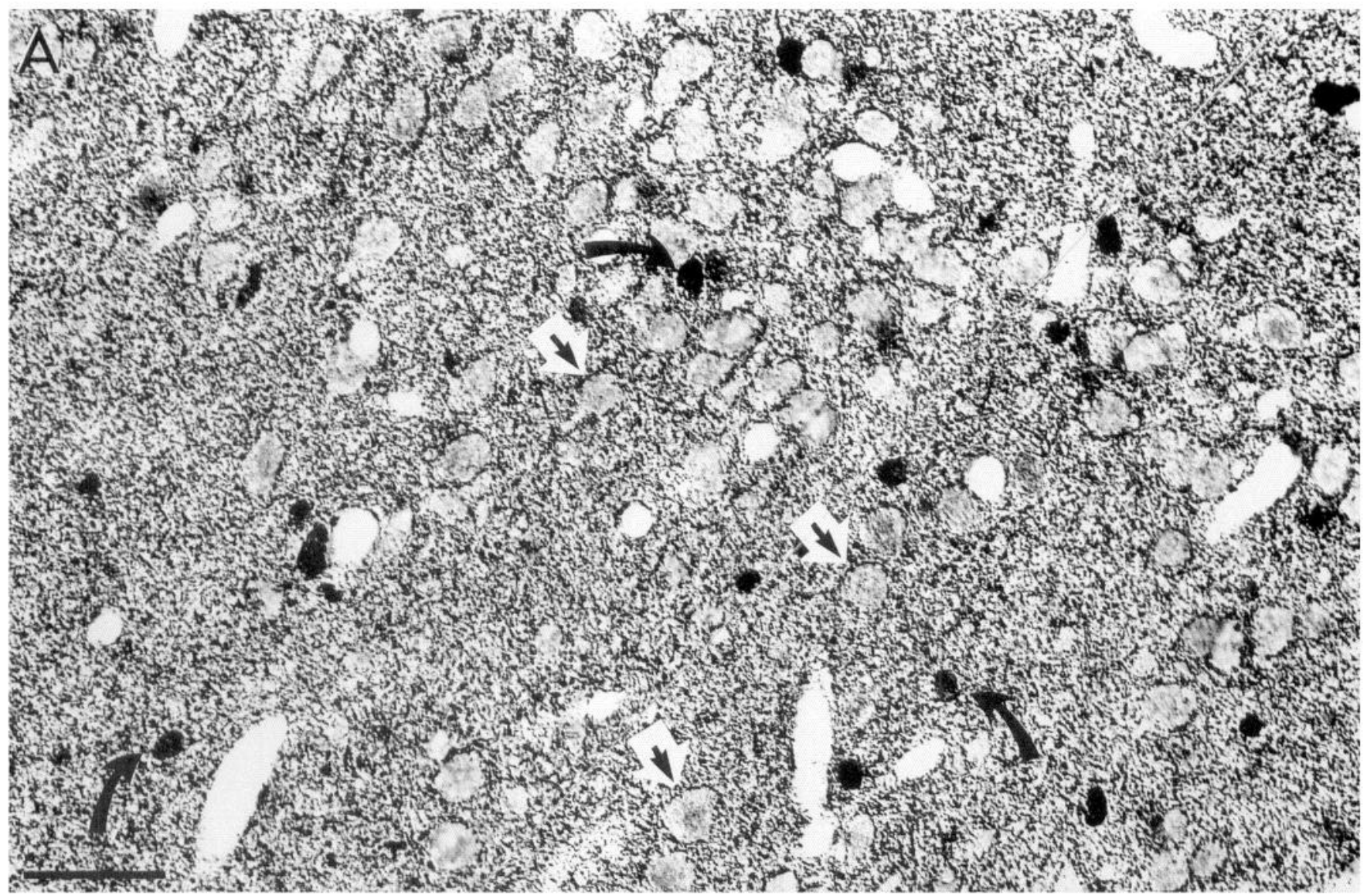
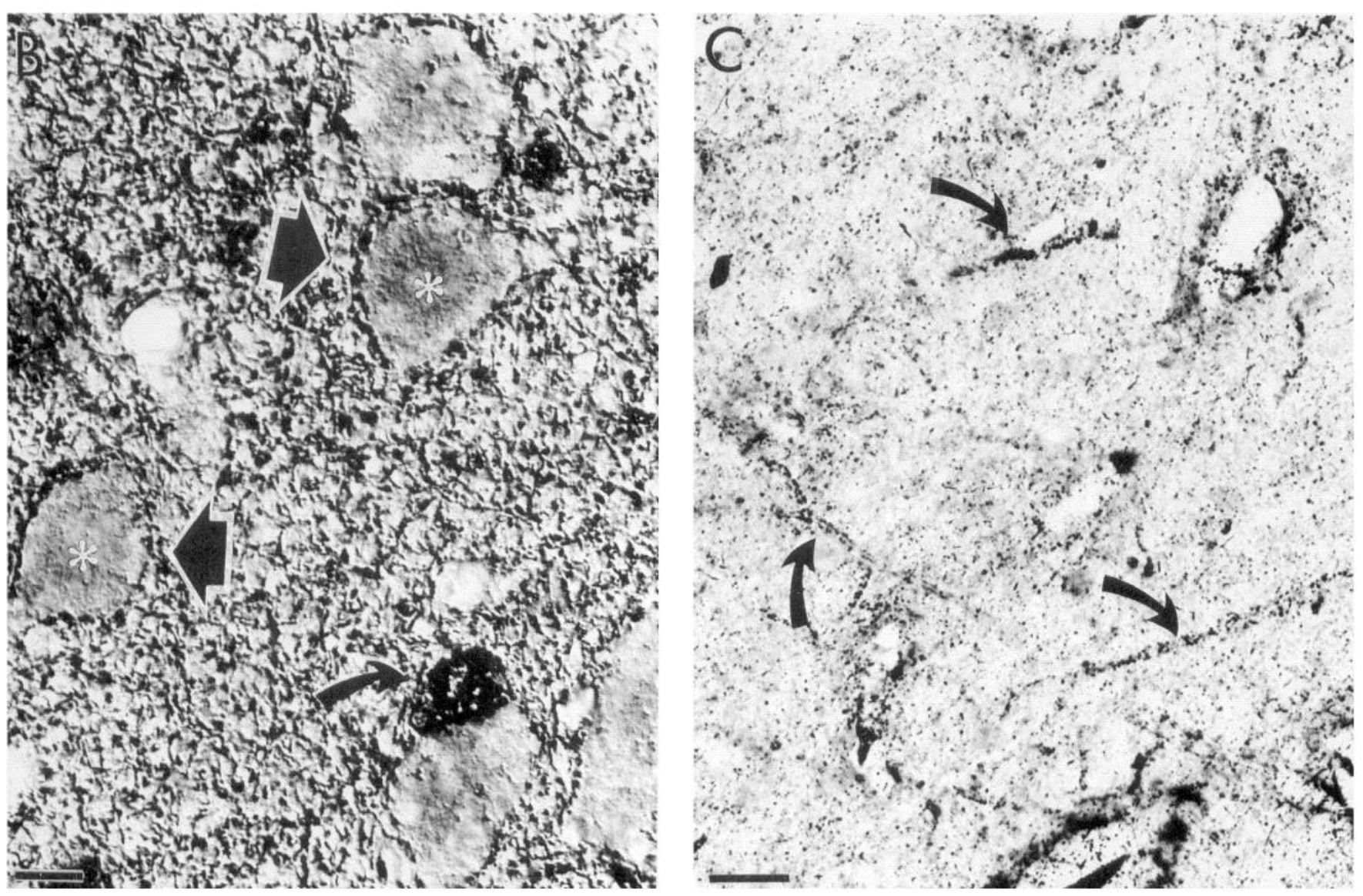


\begin{tabular}{|c|c|c|c|c|c|}
\hline Amygdaloid area & Subdivision & $\begin{array}{l}\text { GABA } \\
\text { cells }\end{array}$ & $\begin{array}{l}\text { GABA } \\
\text { neuropil }\end{array}$ & $\begin{array}{l}G_{A D} D_{65} \\
\text { mRNA }\end{array}$ & $\begin{array}{l}\mathrm{GAD}_{67} \\
\text { mRNA }\end{array}$ \\
\hline Lateral nucleus & & +++ & +++ & ++ & +++ \\
\hline \multirow[t]{3}{*}{ Basal nucleus } & Magnocellular & ++ & ++ & + & ++ \\
\hline & Intermediate & $+t$ & ++ & + & ++ \\
\hline & Parvicellular & ++ & ++ & + & ++ \\
\hline \multirow[t]{3}{*}{ Accessory basal nucleus } & Magnocellular & $++t$ & ++ & ++ & $+t+$ \\
\hline & Parvicellular & +++ & ++ & $+t$ & +++ \\
\hline & Ventromedial & +++ & ++ & ++ & +++ \\
\hline Paralaminar nucleus & & + & 1 & । & $t$ \\
\hline Anterior cortical nucleus & & + & +++ & +++ & +++ \\
\hline Medial nucleus & & + & ++++ & ++++ & ++++ \\
\hline Posterior cortical nucleus & & +++ & +++ & ++ & ++ \\
\hline Amygdalohippocampal area & & +++ & +++ & ++ & ++ \\
\hline Periamygdaloid cortex 2 & & +++ & +++ & +++ & +++ \\
\hline Periamygdaloid cortex 3 & & +++ & +++ & +++ & +++ \\
\hline \multicolumn{6}{|l|}{ Periamygdaloid cortex, sulcal } \\
\hline portion & & +++ & +++ & +++ & +++ \\
\hline \multicolumn{6}{|l|}{ Nucleus of the lateral olfactory } \\
\hline tract & & $+t+$ & +++ & $+t+$ & +++ \\
\hline \multirow[t]{2}{*}{ Central nucleus } & Medial & + & ++++ & ++++ & ++++ \\
\hline & Lateral & + & ++++ & +++ & +++ \\
\hline Anterior amygdaloid area & & + & ++ & + & + \\
\hline Intercalated nuclei & & +++ & +++ & +++ & $++t$ \\
\hline
\end{tabular}

The number of cells and the density of neuropil staining are expressed as ++++ , very high;,+++ high;,++ medium; + , low.

obvious difference in the distribution or density of cells in the ventrolateral and dorsomedial divisions of the nucleus (Fig. 2). In the lateral nucleus, and throughout much of the amygdala, the GABA-ir cells tended to be organized in small clusters separated by acellular regions. The distribution of cell cross-sectional areas of the three types of GABA-ir cells in the lateral nucleus is illustrated in Figure $11 A$. Most $(77 \%)$ of the GABAir cells had type 1 morphology. Scattered among the type 1 cells were a few large, multipolar type 2 cells (14\%) and fewer (9\%) fusiform type 3 cells.

We have attempted to arrive at a rough estimate of the proportion of GABA-ir neurons in the lateral nuclcus. In adjacent sections in which all GABA-ir neurons (Fig. 2C) or all Nisslstained neurons (Fig. 2C) were counted, there were 1297 GABApositive cells and 6509 Nissl-stained neurons. Thus, the population of GABA-ir cells accounted for approximately $20 \%$ of the neurons in the lateral nucleus.

The density of $\mathrm{GAD}_{65}$ mRNA (109 cells $\left./ \mathrm{mm}^{2}\right)$ and $\mathrm{GAD}_{67}$ mRNA (117 cells $/ \mathrm{mm}^{2}$ ) containing cells in the lateral nucleus was slightly lower than the density of GABA-ir cells (Table 2; Figs. $6,7,11 C$ ). Since these counts are based on analyses of a limited number of sections, we do not wish to stress the differences in the amount of labeling in the immunohistochemical and in situ preparations except for those regions where both in situ probes showed substantially different counts from the immunohistochemical preparations, such as in the central nucleus.

GABA staining of fibers and terminals in the lateral nucleus was denser than in any of the other deep nuclei (Table 1). The ventrolateral portion of the lateral nucleus had a somewhat higher density of punctate neuropil staining and many unstained neurons in this region were surrounded by immunopositive varicosities.

The lateral capsular nuclei are small, cell-dense patches located at the lateral margin of the lateral nucleus (Amaral and Bassett, 1989). These small nuclei had about the same density of $\mathrm{GABA}$-ir and $\mathrm{GAD}_{65}$ - and $\mathrm{GAD}_{67}$-positive cells as the lateral nucleus but fiber and terminal labeling was distinctly higher.

Basal nucleus. The density of GABA-ir cells in the basal nucleus $\left(90\right.$ cells $\left./ \mathrm{mm}^{2}\right)$ was slightly lower than in the lateral and accessory basal nuclei (Figs. 2, 11C). The density of GABA-ir cells was similar in the magnocellular $\left(79\right.$ cells $\left./ \mathrm{mm}^{2}\right)$ and intermediate divisions $\left(72\right.$ cells $/ \mathrm{mm}^{2}$ ) of the basal nucleus and slightly higher in the parvicellular division $\left(102 \mathrm{cells} / \mathrm{mm}^{2}\right)$. Type 1 cells were most common throughout the basal nucleus and type 2 cells were mainly observed in the intermediate and parvicellular divisions (Fig. $4 D, E$ ); very few type 3 cells were seen in the basal nucleus. The density of GAD mRNA-labeled cells was also slightly lower in the basal nucleus $\left(\mathrm{GAD}_{65}, 70\right.$

Figure 5. A, Bright-field photomicrograph that shows GABA-ir basket plexuses (black on white arrows) around unstained somata in the nucleus of the lateral olfactory tract. Curved arrows indicate GABA-ir neurons (Nomarski optics). $B$, A higher-magnification photomicrograph taken with Nomarski optics in the parvicellular division of the basal nucleus that shows immunoreactive varicosities (straight arrows) surrounding unstained neuronal cell bodies (asterisks) in a basket-like manner. Curved arrow points to a GABA-ir neuron. $C$, Bright-field photomicrograph that shows linear profiles resembling "woolly fibers" found especially in the central nucleus. Scale bars: $A, 50 \mu \mathrm{m} ; B, 10 \mu \mathrm{m} ; C, 25 \mu \mathrm{m}$. 


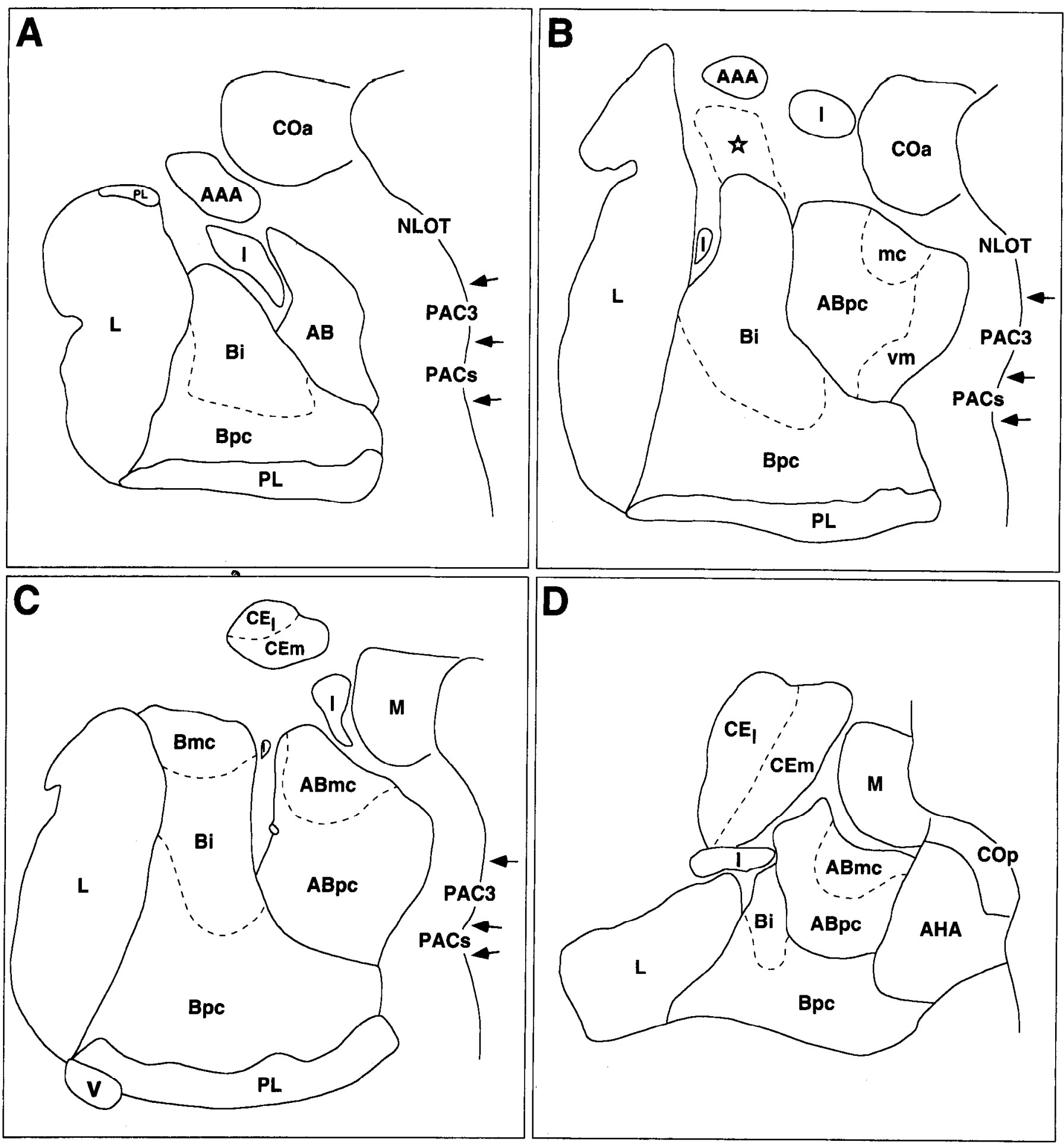

Figure 6. Expression of $\mathrm{GAD}_{67} \mathrm{mRNA}$ in different nuclei of the monkey amygdala (monkey M5-91, left amygdala). The panels at left illustrate outlines of different amygdaloid nuclei that were drawn from Nissl-stained sections adjacent to the autoradiograms shown at right. Star symbol in $B(l e f t)$ indicates the beginning of the magnocellular division of the basal nucleus. The panels at right show dark-field photomicrographs of autoradiograms that demonstrate the distribution of $\mathrm{GAD}_{67} \mathrm{mRNA-expressing} \mathrm{neurons.} \mathrm{Arrows} \mathrm{indicate} \mathrm{boundaries} \mathrm{between} \mathrm{superficial} \mathrm{regions.}$ For abbreviations, see Figure 2 . Scale bar $(A, r i g h t), 1 \mathrm{~mm}$ for all panels.

cells $/ \mathrm{mm}^{2} ; \mathrm{GAD}_{67}, 90$ cells $\left./ \mathrm{mm}^{2}\right)$ than in the lateral and accessory basal nuclei (Figs. 6, 7, 11C).

The overall density of GABA-ir fiber and terminal labeling in the basal nucleus was lower than in the lateral nucleus (Table 1). Within the basal nucleus, a slightly higher density of GABAir fibers and terminals was observed in the magnocellular and intermediate divisions than in the parvicellular division. One characteristic feature of the magnocellular division of the basal nucleus was the appearance of numerous pericellular baskets; these surrounded the unstained somas of the large cells that populate this region (Fig. 5B).

Paralaminar nucleus. The paralaminar nucleus forms the 

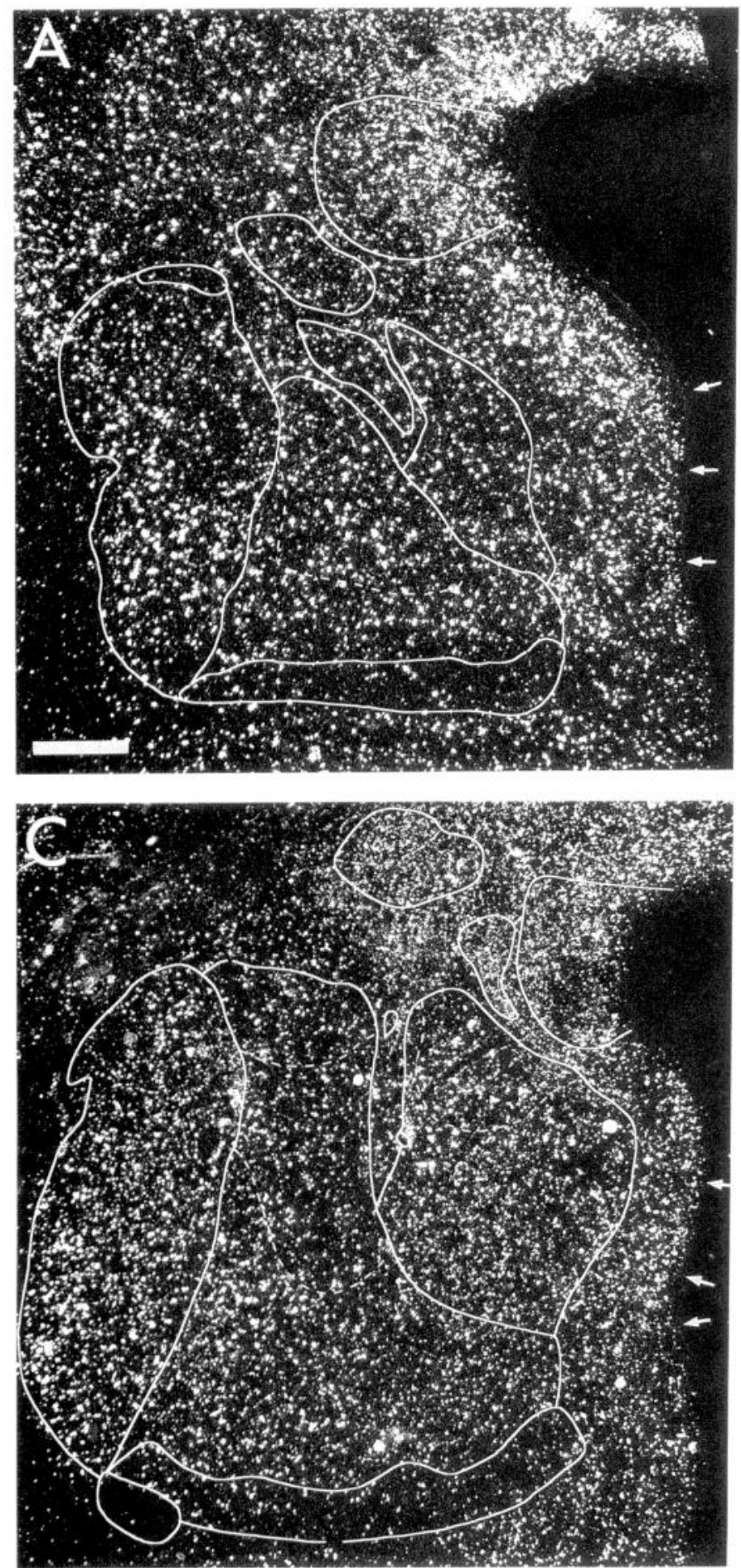

Figure 6. Continued.

ventral and rostral borders of the basal nucleus. There was a marked decrease in the number of GABA-ir cells $\left(65\right.$ cells $\left./ \mathrm{mm}^{2}\right)$ as one moved from the parvicellular division of the basal nucleus into the paralaminar nucleus (Fig. $2 A^{\prime}-D^{\prime}$ ) and most of the labeled cells were type 1 . The in situ hybridization preparations confirmed the low number of GABAergic cells $\left(\mathrm{GAD}_{65}\right.$, 25 cells $/ \mathrm{mm}^{2} ; \mathrm{GAD}_{67}, 30$ cells $/ \mathrm{mm}^{2}$; Figs. 6, 7, 11C). GABAir neuropil staining in the paralaminar nucleus was also quite low (Table 1).
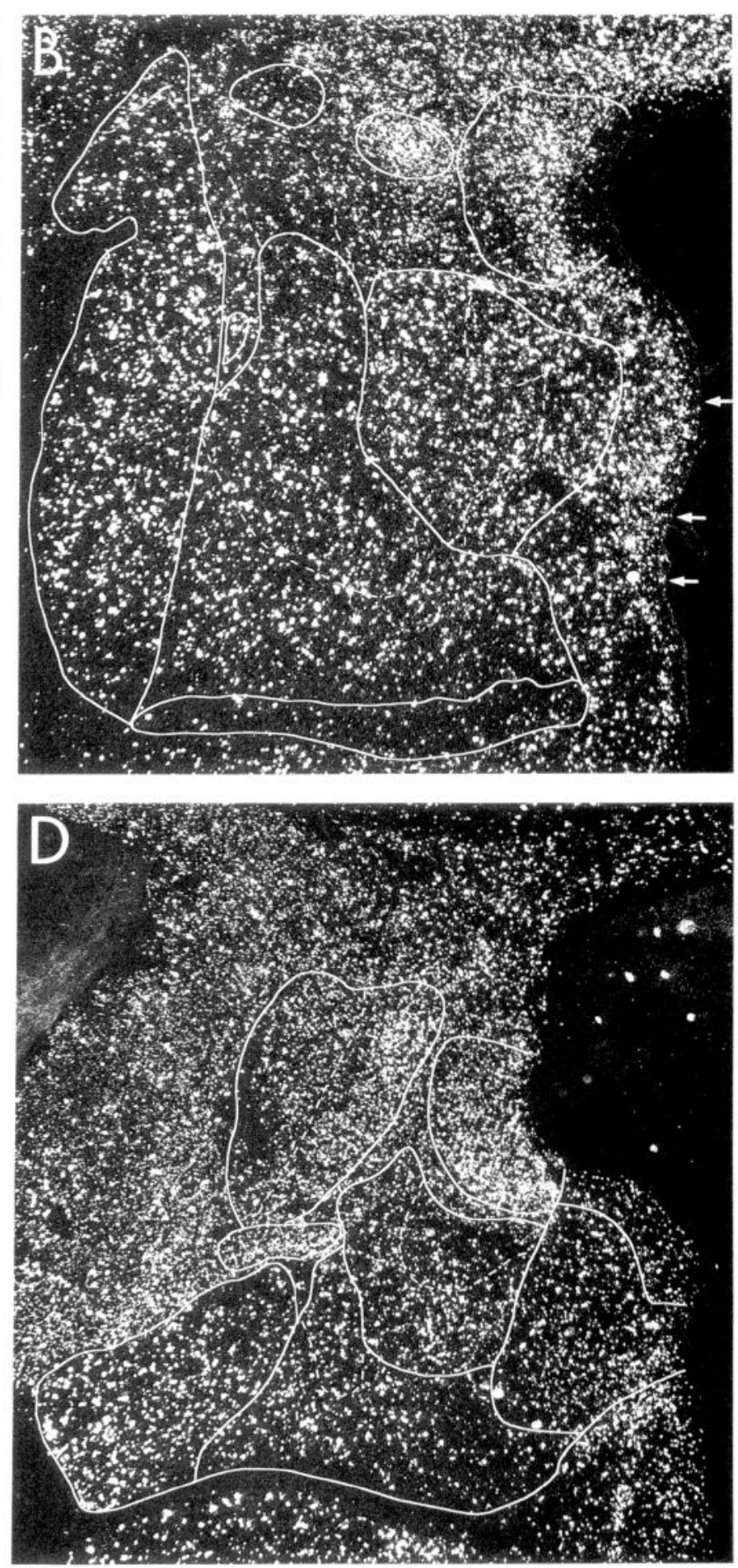

Accessory basal nucleus. All divisions of the accessory basal nucleus had a relatively high density of GABA-ir cells ( 113 cells/ $\mathrm{mm}^{2}$ ) (Fig. 2, Table 1). Most of the GABA-ir cells were type 1, though type 2 cells were also seen. Cells expressing GAD were evenly distributed throughout the accessory basal nucleus (Figs. $6,7)$. The density of labeled cells $\left(\mathrm{GAD}_{65}, 108 \mathrm{cclls} / \mathrm{mm}^{2} ; \mathrm{GAD}_{67}\right.$, 146 cells $/ \mathrm{mm}_{2}$ ) was higher than in the basal nucleus but lower than in the adjacent periamygdaloid cortex. The accessory basal nucleus had a medium density of neuropil labeling with a slightly 


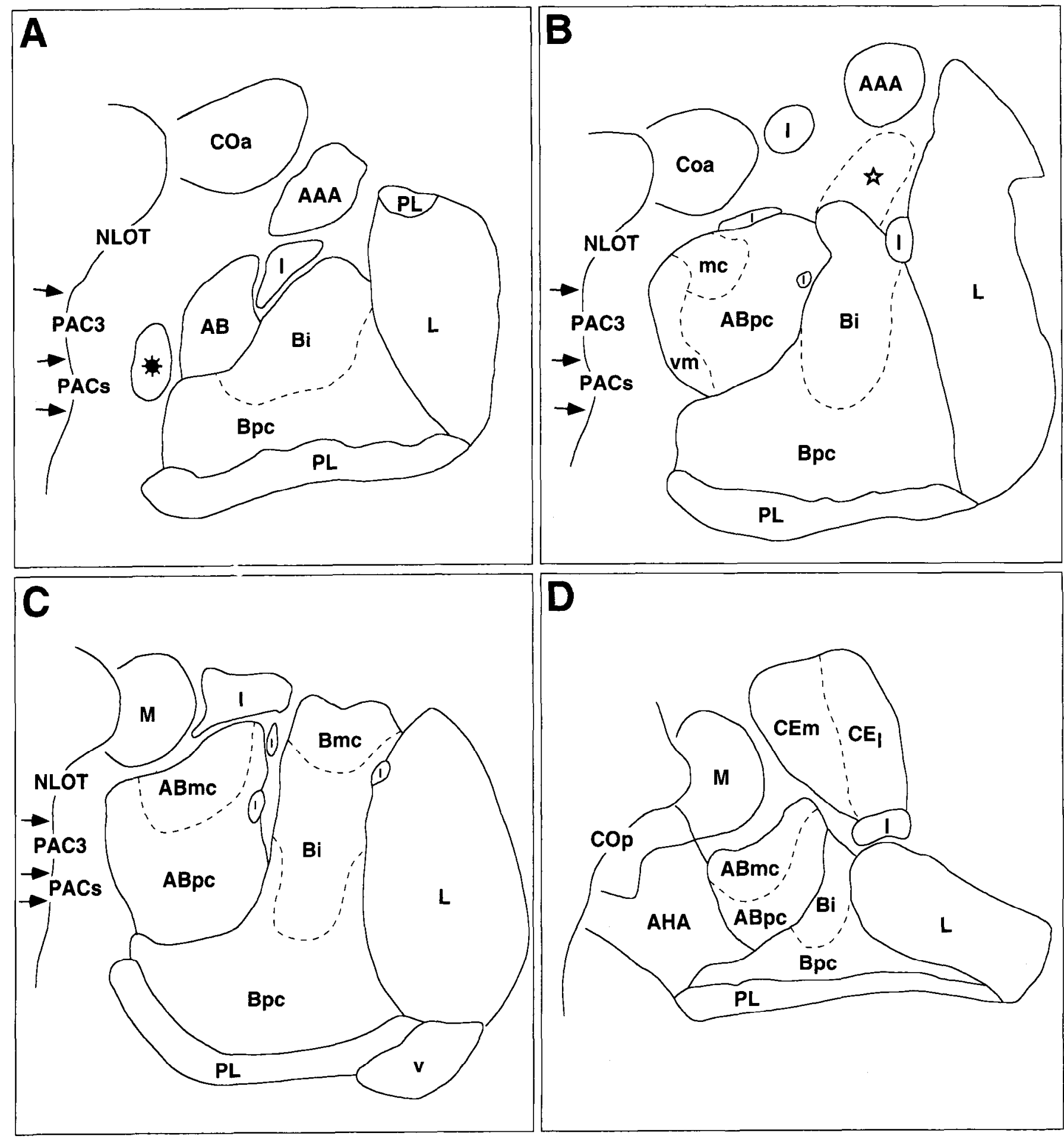

Figure 7. Expression of $\mathrm{GAD}_{\mathrm{bs}}$ mRNA in different nuclei of the monkey amygdala (monkey M5-91, right amygdala). The panels at left illustrate outlines of different amygdaloid nuclei that were drawn from Nissl-stained sections adjacent to the autoradiograms shown at right. Asterisk-shaped symbol in $A$ (left) indicates a cluster of darkly stained cells that could not easily be related to any of the previously identified amygdaloid regions. Star symbol in $B$ (left) indicates the beginning of the magnocellular division of the basal nucleus. The panels at right show dark-field photomicrographs of autoradiograms that demonstrate the distribution of $\mathrm{GAD}_{65}$ mRNA-expressing neurons. For abbreviations, see Figure 2 . Scale bar $(A$, right), 1 $\mathrm{mm}$ for all panels.

higher density of immunoreactive fibers and terminals in the ventromedial division (Table 1).

\section{Superficial nuclei}

Nucleus of the lateral olfactory tract. The number of GABA-ir cells in the nucleus of the lateral olfactory tract $\left(119 \mathrm{cells} / \mathrm{mm}^{2}\right)$ was higher than in the dorsally adjacent anterior cortical and medial nuclei and about the same as in the deep nuclei (Fig. $2 A^{\prime}, B^{\prime}$ ). In layer Il, the GABA-ir neurons were scattered among unstained neuronal profiles that were outlined by immunoreactive varicosities. The great majority of labcled cells wcre type 1. There was a substantially higher density of cells with $\mathrm{GAD}_{65}$ 

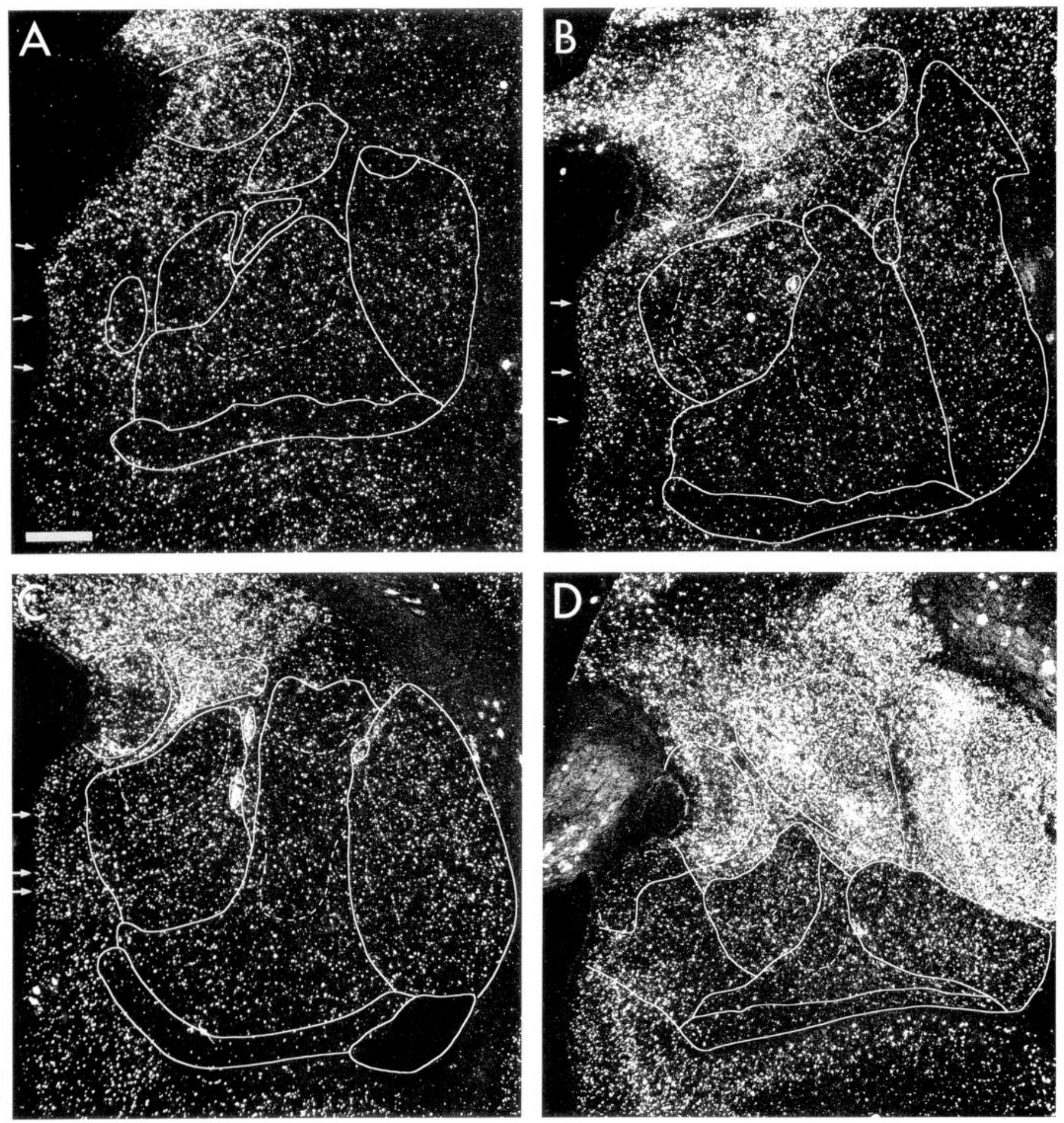

Figure 7. Continued.

(206 cells $\left./ \mathrm{mm}^{2}\right)$ and $\mathrm{GAD}_{67}$ mRNAs $\left(219\right.$ cells $\left./ \mathrm{mm}^{2}\right)$ than were GABA-ir but the distribution of the labeled cells was similar (Figs. 6, 7). GABA-ir fiber and terminal labeling was high in the nucleus of the lateral olfactory tract and much of the neuropil labeling was composed of basket-like pericellular plexuses.

Periamygdaloid cortex. The distribution of GABA-ir neurons and neuropil as well as the distribution of cells that contained GAD mRNA was quite similar throughout the periamygdaloid cortex. The density of GABA-ir neurons in the periamygdaloid cortex was high (Fig. 2). The density of in situ labeled cells closely matched the number of GABA-ir cells (Fig. $11 \mathrm{C}$ ). The density of $\mathrm{GAD}_{67} \mathrm{mRNA}$ and $\mathrm{GAD}_{65}$ mRNA in situ labeled cells in the periamygdaloid cortex was noticeably higher than in the deep nuclei of the amygdala (Figs. 6, 7). The density of GABA-ir neuropil staining was consistently high throughout the periamygdaloid cortex (Table 1) and numerous pericellular baskets surrounding unstained neuronal profiles were found in layer II.

Anterior cortical nucleus. The anterior cortical nucleus had 

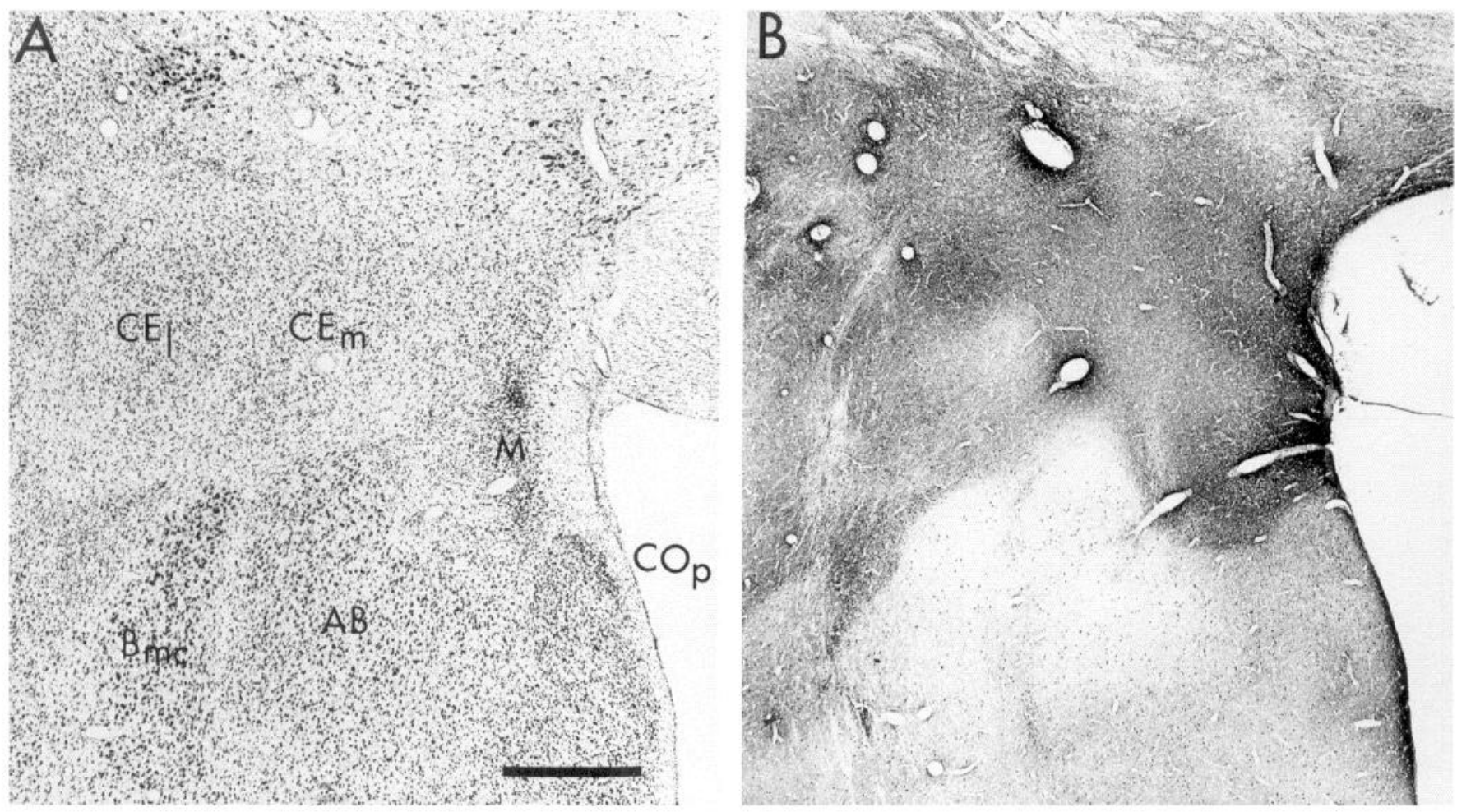

Figure 8. A, Bright-field photomicrograph of a Nissl-stained section from the caudal portion of the amygdala. $B$, A bright-field photomicrograph of a section adjacent to the one illustrated in $A$. This one has been immunohistochemically processed for the distribution of GABA. Note that there is substantially greater GABA immunoreactivity in the central and medial nuclei than in the basal and accessory basal nuclei. Most of this reaction product is associated with fibers and varicosities. For abbreviations, see Figure 2. Scale bar, $1 \mathrm{~mm}$.

one of the lower densities of GABA-ir cells in the amygdala (61 cells $/ \mathrm{mm}^{2}$ ) (Fig. $2 A^{\prime}, B$ ). Most of the GABA-ir cells were type 1 , were located in layers II and III, and were ovoid or spherical in shape without visible processes. The density of cells that contained $\mathrm{GAD}_{65}$ mRNA (182 cells $/ \mathrm{mm}^{2}$ ) and $\mathrm{GAD}_{67}$ mRNA $\left(232\right.$ cells $/ \mathrm{mm}^{2}$ ) was clearly higher than the density of GABAir cells (compare Fig. $2 A^{\prime}, B^{\prime}$ with Figs. $6 A, B, 7 A, B$ ). In fact, the anterior cortical nucleus had one of the highest densities of in situ labeled cells in the amygdala (Fig. $11 C$ ). The density of GABA-ir neuropil staining was also quite high in the anterior cortical nucleus (Table 1). Many of the stained fibers and varicosities in layer II formed basket-like plexuses around unstained somas.

Medial nucleus. The pattern of labeling in the medial nucleus was very similar to that in the anterior cortical nucleus. The density of GABA-ir neurons was very low $\left(45\right.$ cells $/ \mathrm{mm}^{2}$ ) (Fig. $\left.2 C^{\prime}, D^{\prime}\right)$ but the density of cells positive for GAD mRNA $\left(\mathrm{GAD}_{65}\right.$, 174 cells $/ \mathrm{mm}^{2} ; \mathrm{GAD}_{67}, 179$ cells $/ \mathrm{mm}^{2}$ ) was very high (Figs. 6, $7,11 C)$. At anterior levels of the medial nucleus, labeled cells were preferentially located in the superficial portion of layer II and in the deep portion of layer III. In the caudal portion of the medial nucleus, labeled cells were more homogeneously distributed throughout layers II and III.

The level of GABA-ir neuropil staining in the medial nucleus was among the highest in the monkey amygdaloid complex (Table 1). Pericellular baskets in layer II were even more prominent than in the anterior cortical nucleus. A densely immunoreactive fiber bundle was located immediately lateral to the medial nucleus.

Posterior cortical nucleus. The posterior cortical nucleus had a very high number of type 1 GABA-ir neurons $\left(222\right.$ cells $/ \mathrm{mm}^{2}$ ) (Fig. 2D). Overall, there was a slightly lower density of in situ labeled cells $\left(\mathrm{GAD}_{67}\right.$ mRNA, 171 cells $/ \mathrm{mm}^{2} ; \mathrm{GAD}_{65} \mathrm{mRNA}$, $116 \mathrm{cells} / \mathrm{mm}^{2}$ ) (Figs. 6, 7, 11C). There was dense GABA-ir neuropil staining in the posterior cortical nucleus (Table 1). In the superficial portion of layer II, there were numerous basket plexus profiles.

\section{Other nuclei}

Anterior amygdaloid area. The number of cells found to be GABA-ir or to contain GAD mRNAs was about equal to that observed in the deep nuclei. The GABA-ir neuropil staining in the anterior amygdaloid area was also similar to that in the deep nuclei.

Central nucleus. The central nucleus proved to have one of the most complex distributions of GABAergic markers in our preparations. It had the lowest density $\left(31\right.$ cells $\left./ \mathrm{mm}^{2}\right)$ of GABAir cells in the monkey amygdaloid complex (Figs. $2 C^{\prime}, D^{\prime}, 11 C$ ). The GABA-ir cells were typically type 1 , which rarely demonstrated a clearly identifiable dendritic tree; an occasional fusiform cell was also observed in the central nucleus.

Given the low number of GABA-ir neurons, it was somewhat surprising that the central nucleus had the highest density of cells containing GAD mRNAs $\left(\mathrm{GAD}_{65}, 281 / \mathrm{mm}^{2} ; \mathrm{GAD}_{67}, 257 /\right.$ $\mathrm{mm}^{2}$ ) (Figs. 6, 7, 11C). The number of labeled cells was approximately the same in the medial and lateral subdivisions of the central nucleus. Interestingly, the density of silver grains observed over neurons in the central nucleus was substantially lower than over labeled cells in other areas, such as the lateral nucleus (Fig. 9). 


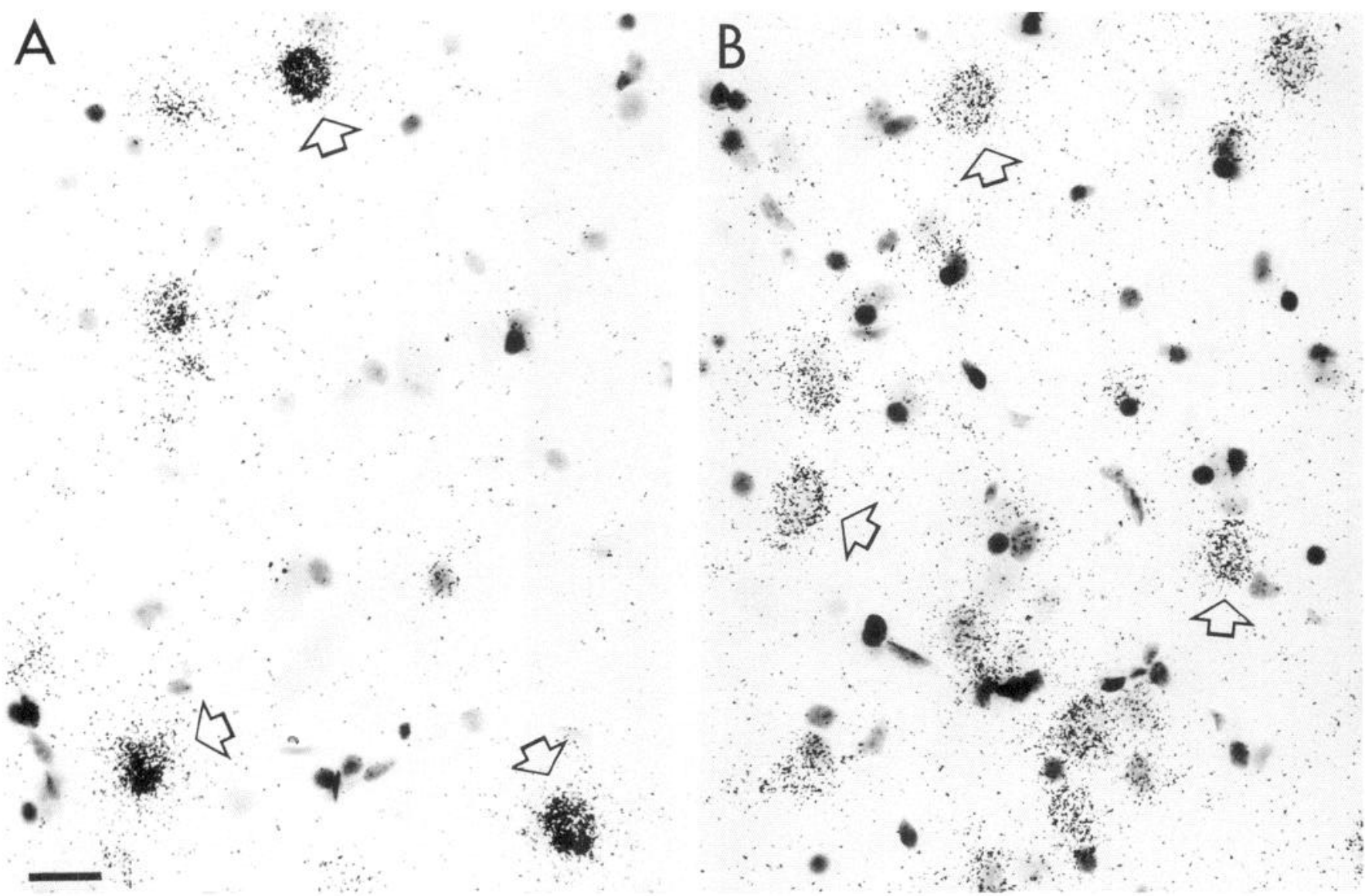

Figure 9. Expression of $\mathrm{GAD}_{65}$ mRNA in the lateral nucleus $(A)$ and in the medial division of the central nucleus $(B)$. Open arrows indicate labeled cells. Note the higher grain density over cells in the lateral nucleus compared to those in the central nucleus. Scale bar, $20 \mu \mathrm{m}$.
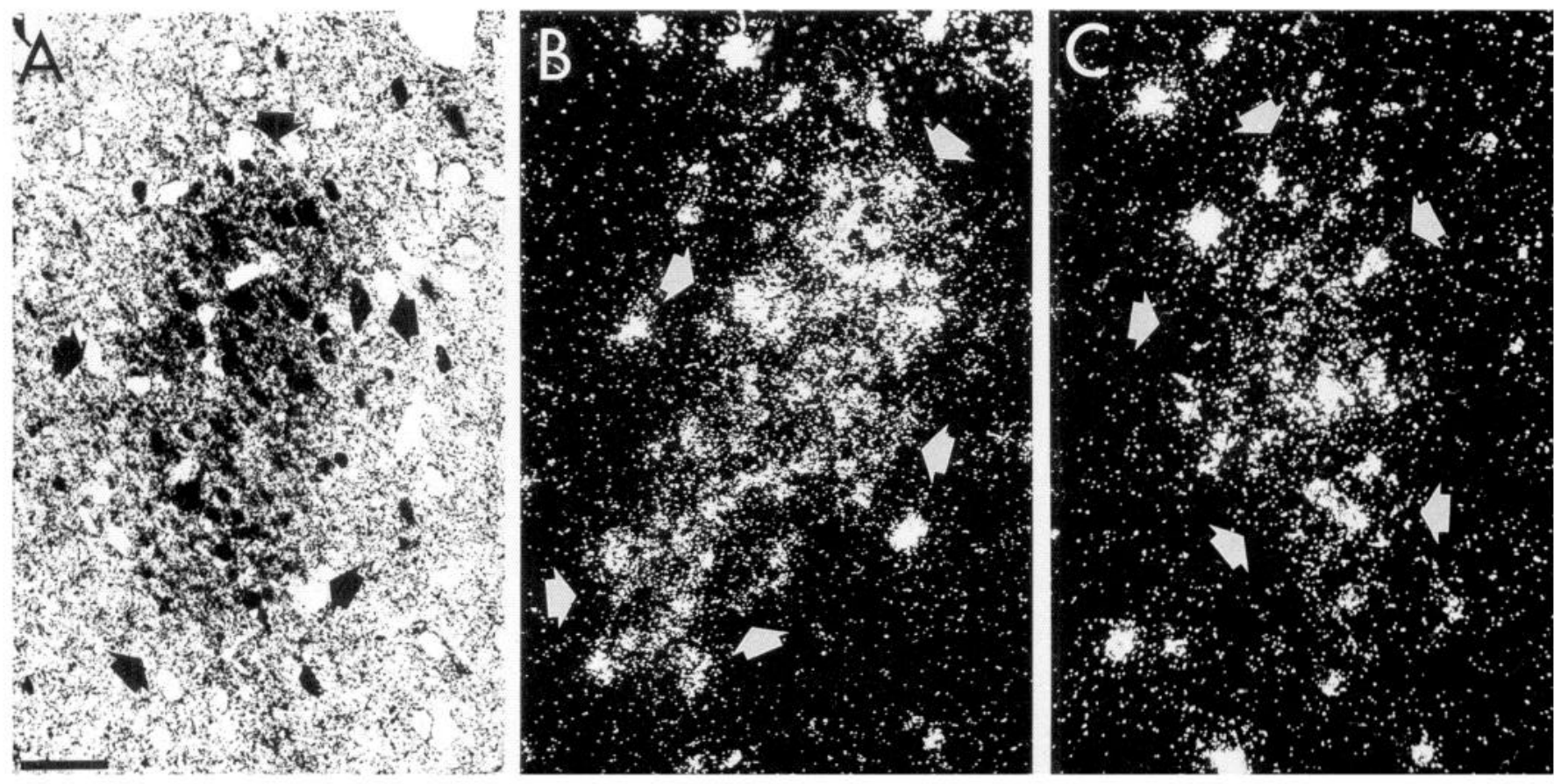

Figure 10. A, Silver-intensified immunohistochemical preparation of GABA-positive cells in the intercalated nucleus. $B$, Dark-field photomicrograph illustrating expression of $\mathrm{GAD}_{65}$ mRNA in the intercalated nucleus. $C$, Dark-field photomicrograph illustrating expression of $\mathrm{GAD}_{67} \mathrm{mRNA}$ in the intercalated nucleus. Arrows indicate the boundaries of the intercalated nucleus. Scale bar, $50 \mu \mathrm{m}$. 


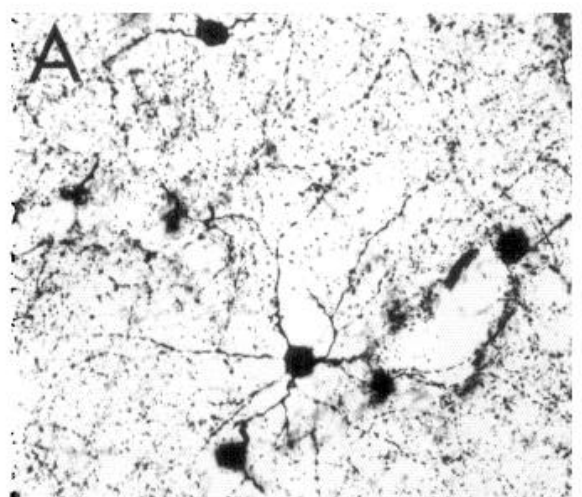

b. 1 int

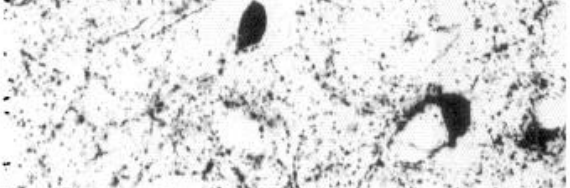

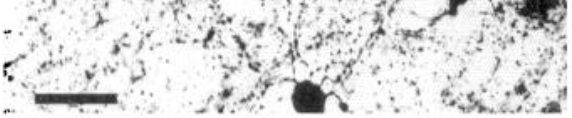
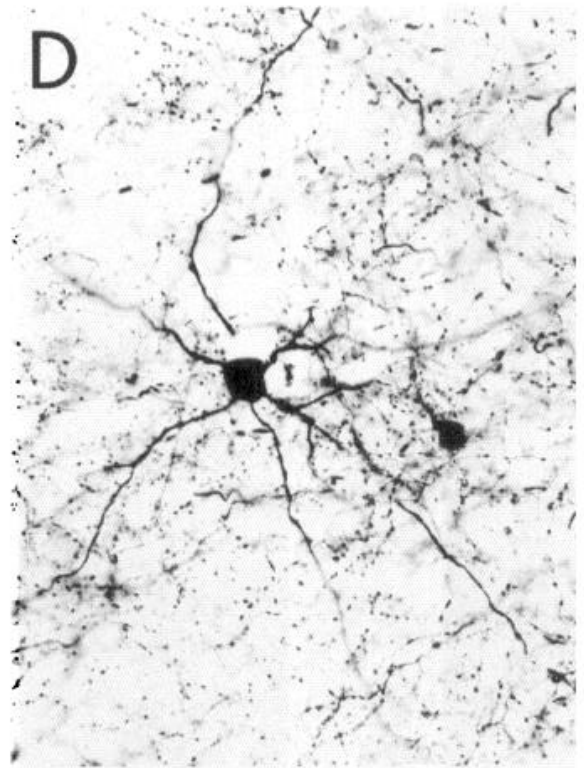

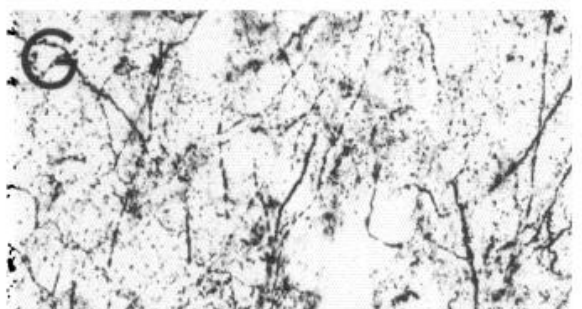

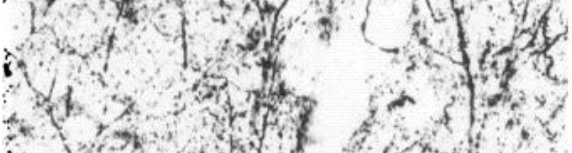

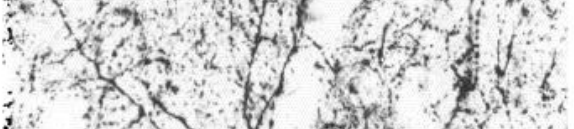

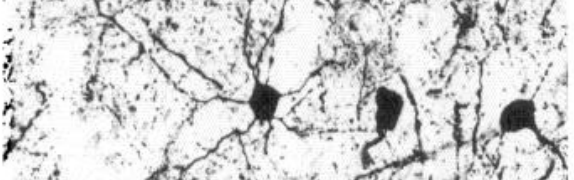
10 of 1 mf

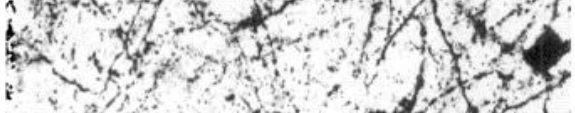
$x^{2}+y^{2} y+2$

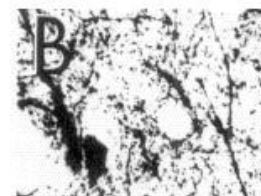

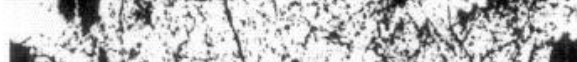

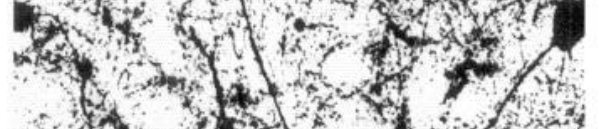

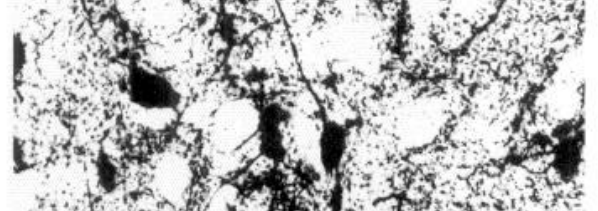

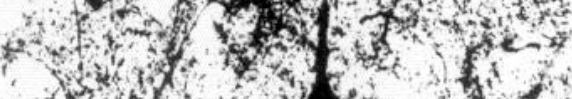

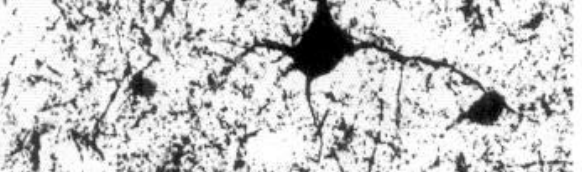

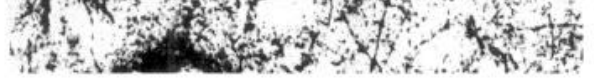
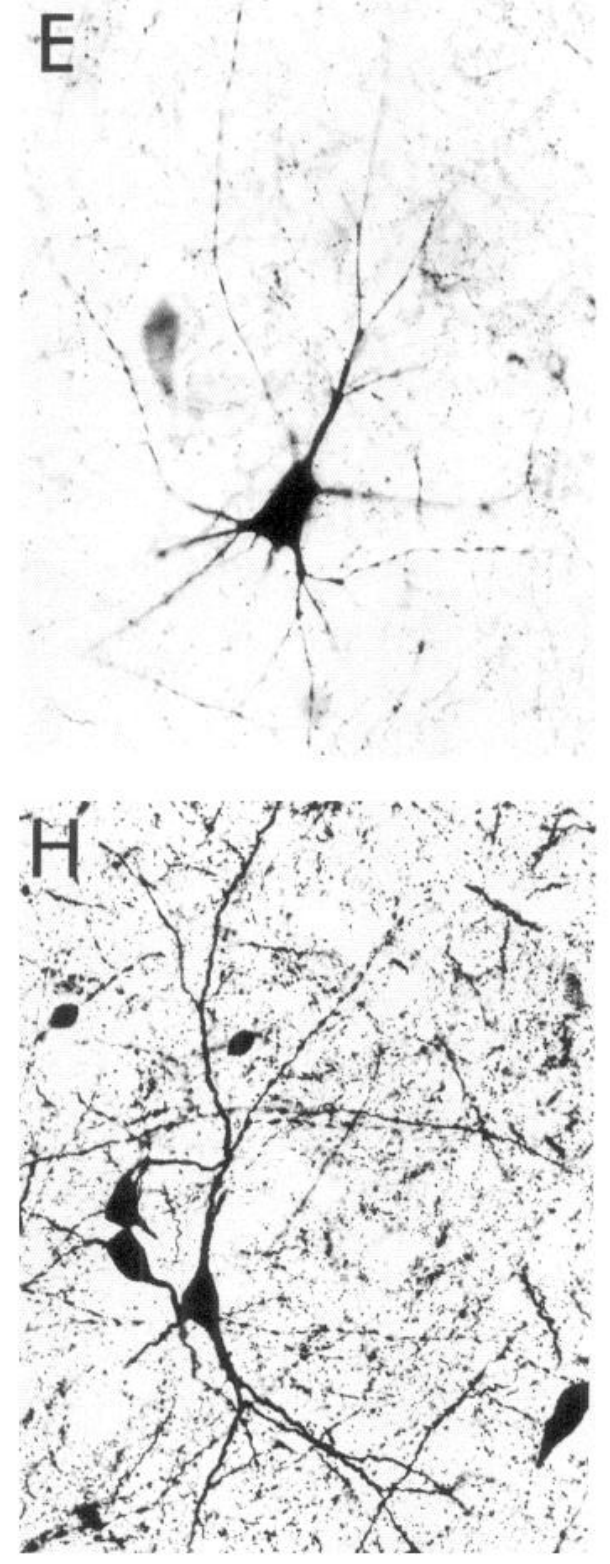

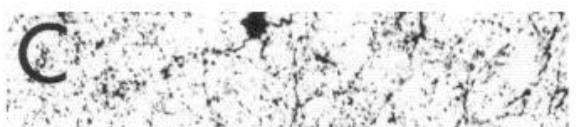

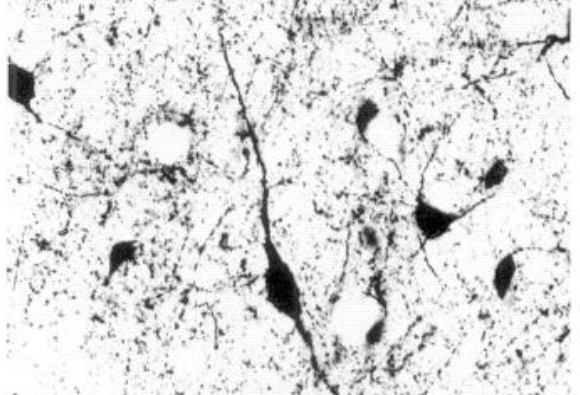

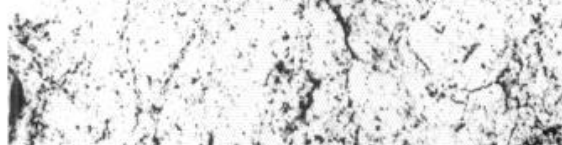

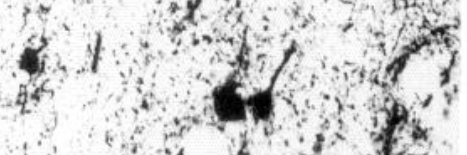
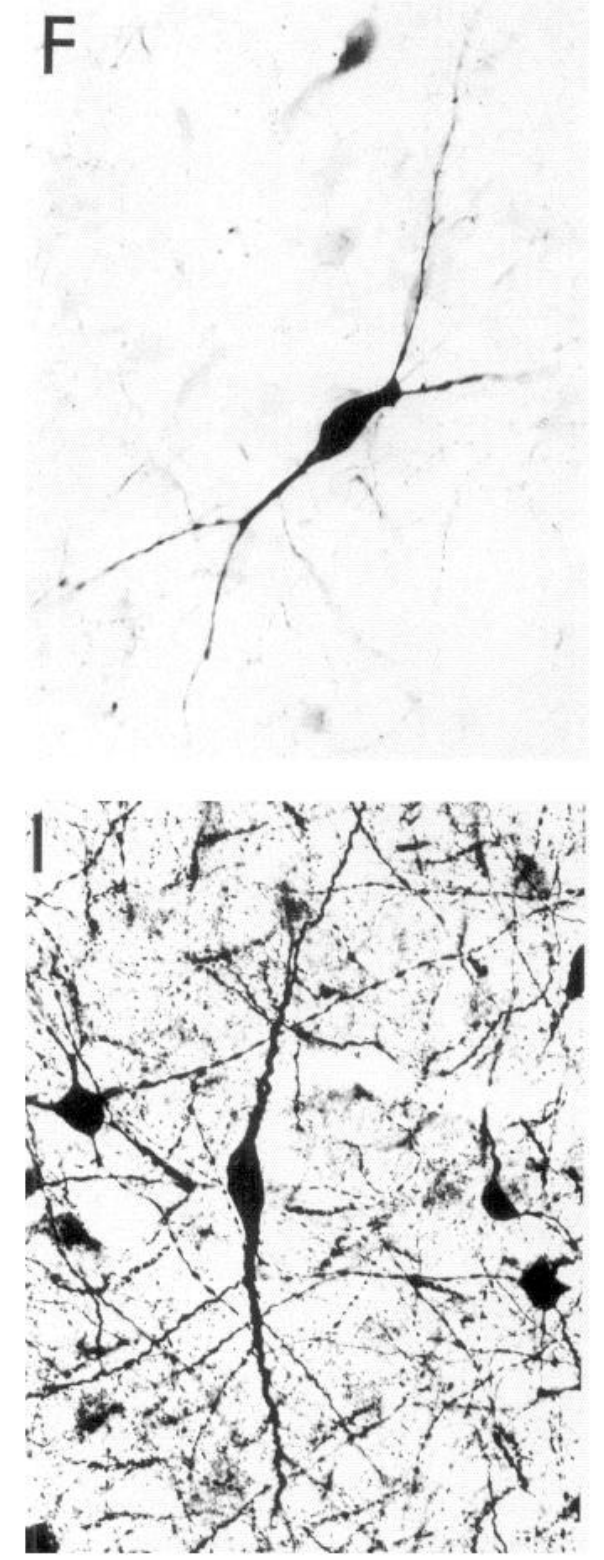


\begin{tabular}{|c|c|c|c|c|c|c|c|}
\hline Cell type & Immunoreactivity & $\begin{array}{l}\text { Cell } \\
\text { number }\end{array}$ & $\begin{array}{l}\% \text { of } \\
\text { cells }\end{array}$ & $\begin{array}{l}\text { Cells/ } \\
\mathrm{mm}^{2}\end{array}$ & $\begin{array}{l}\text { Mean size } \pm \text { SD } \\
\left(\mu \mathrm{m}^{2}\right)\end{array}$ & $\begin{array}{l}\text { Minimum } \\
\left(\mu \mathbf{m}^{2}\right)\end{array}$ & $\begin{array}{l}\text { Maximum } \\
\left(\mu \mathrm{m}^{2}\right)\end{array}$ \\
\hline \multirow[t]{3}{*}{ All types } & GABA & 1297 & 100 & 148 & $95 \pm 39$ & 33 & 297 \\
\hline & Parvalbumin & 443 & 100 & 56 & $115 \pm 50$ & 38 & 357 \\
\hline & Calbindin- $\mathrm{D}_{28 \mathrm{k}}$ & 478 & 100 & 57 & $114 \pm 50$ & 42 & 337 \\
\hline \multirow[t]{3}{*}{ Type 1} & GABA & 1002 & 77 & 115 & $82 \pm 24$ & 33 & 242 \\
\hline & Parvalbumin & 280 & 63 & 35 & $95 \pm 28$ & 38 & 205 \\
\hline & Calbindin- $\mathrm{D}_{28 \mathrm{k}}$ & 384 & 80 & 46 & $102 \pm 40$ & 42 & 263 \\
\hline \multirow[t]{3}{*}{ Type 2} & GABA & 183 & 14 & 21 & $150 \pm 46$ & 66 & 297 \\
\hline & Parvalbumin & 110 & 25 & 14 & $158 \pm 64$ & 53 & 357 \\
\hline & Calbindin- $\mathrm{D}_{28 \mathrm{k}}$ & 26 & 6 & 3 & $178 \pm 59$ & 63 & 307 \\
\hline \multirow[t]{3}{*}{ Type 3} & GABA & 112 & 9 & 13 & $122 \pm 42$ & 60 & 262 \\
\hline & Parvalbumin & 53 & 12 & 7 & $133 \pm 49$ & 52 & 247 \\
\hline & Calbindin- $\mathrm{D}_{28 \mathrm{k}}$ & 68 & 14 & 8 & $156 \pm 55$ & 54 & 337 \\
\hline
\end{tabular}

SD, standard deviation of mean. Minimum and maximum refer to the smallest and largest cell areas found in the specified region.

In contrast to the low density of GABA-ir cells, the central nucleus had one of the highest densities of GABA-ir fiber and terminal labeling (Fig. 8, Table 1). There were no clear differences in the density of neuropil labeling in the medial and lateral divisions of the central nucleus. Fiber and terminal labeling had a diffuse appearance, and there were few baskct-likc plexuscs. We did, however, observe long, often transversely oriented thick profiles that were made up of parallel strings of immunoreactive varicosities (Fig. $5 C$ ). These were particularly prominent in the lateral division of the nucleus and were possibly segments of dendrites studded with GABAergic varicosities. They resembled the so-called "woolly fibers" (Haber and Elde, 1982; Haber and Nauta, 1983; Amaral et al., 1989) that have been reported in the amygdala and substantia innominata in peptide immunohistochemical preparations.

Amygdalohippocampal area. The amygdalohippocampal area contained a very high number of GABA-ir neurons ( 198 cells/ $\mathrm{mm}^{2}$ ) that were similar to those in the periamygdaloid cortex (Fig. 2D). Many in situ labeled cells were evenly distributed in the amygdalohippocampal area $\left(\mathrm{GAD}_{67} \mathrm{mRNA}, 158 \mathrm{cells} / \mathrm{mm}^{2}\right.$; $\mathrm{GAD}_{65}$ mRNA, 131 cells $/ \mathrm{mm}^{2}$ ) (Figs. 6, 7, 11C). GABA-ir neuropil staining was also high in the amygdalohippocampal area (Table 1) and basket-like plexuses around unstained cell bodies were common.

Intercalated nuclei. In most of the intercalated nuclei (Fig. $2 A^{\prime}-C^{\prime}$ ) the number of GABA-ir cells was substantially higher than observed in the deep nuclei. In fact, in some intercalated nuclei, essentially all of the small neurons appeared to be labeled (Fig. 10A). However, due to the light staining of individual neurons and the relatively dense neuropil staining in which they were embedded, it was often difficult to visualize stained cell profiles. A few apparent intercalated nuclei demonstrated substantially fewer labeled cells [Fig. 2, $B^{\prime}$ (lateral to anterior cortical nucleus) and $D^{\prime}$ (dorsal to the lateral nucleus)]. A very high number of cells containing GAD mRNAs was also found in the intercalated nuclei (Figs. $6 C ; 7 B, C ; 10 B, C$ ). In these preparations as well, it appeared that essentially all of the neurons in these small, cell-dense islands were labeled in the in situ preparations. The most distinctive feature of the intercalated nuclei, however, was their very high density of fiber and terminal labeling; the immunoreactive plexus of fibers and terminals appeared to be the densest of any nucleus in the monkey amygdaloid complex (Fig. 10A).

\section{$G A B A$ in amygdaloid pathways}

GABA-positive fibers were observed along the entire course of the stria terminalis. Some of these fibers entered the medially adjacent extension of the bed nucleus of the stria terminalis and developed a dense fiber and terminal network there. The relatively high level of fiber and terminal labeling continued into the main portion of the bed nucleus of the stria terminalis, which resembled the central nucleus in having high terminal labeling with a low number of GABA-ir cells. There were also GABAir fibers in the region occupied by the ventral amygdalofugal pathway. But since this region is so heterogeneous it is difficult to know whether these GABA-ir fibers are related to the amygdaloid complex.

\section{Comparison of GABA immunoreactivity to parvalbumin and calbindin- $\mathrm{D}_{28 \mathrm{k}}$ immunoreactivities}

We have previously described the density and cross-sectional area of parvalbumin-ir and calbindin- $\mathrm{D}_{28 \mathrm{k}}$-ir cell types in the lateral nucleus of the monkey amygdala (Pitkänen and Amaral, 1993a,b). In many cortical and subcortical areas, there is substantial colocalization of the calcium-binding proteins and GABA (e.g., see Katsumaru et al., 1988; Hendry et al., 1989). For this reason, it is of some interest to compare the morphological characteristics and distribution of the GABA-ir, parvalbuminir, and calbindin- $\mathrm{D}_{28 \mathrm{k}}$-ir neurons. While differences in fixation and subsequent processing of tissue limits the absolute com-

\footnotetext{
Figure 11. Bright-field photomicrographs of neurons immunoreactive for GABA $(A-C)$, parvalbumin $(D-F)$, and calbindin- $\mathrm{D}_{28 \mathrm{k}}(G-I)$ in the monkey amygdala provide a comparison of morphological cell types visualized with each of these staining procedures. Type 1 cells are illustrated in the left panels $(A, D, G)$, type 2 cclls are shown in the middle panels $(B, E, H)$, and type 3 cells are shown on the right $(C, F, I)$. Scalc bar, $25 \mu \mathrm{m}$.
} 

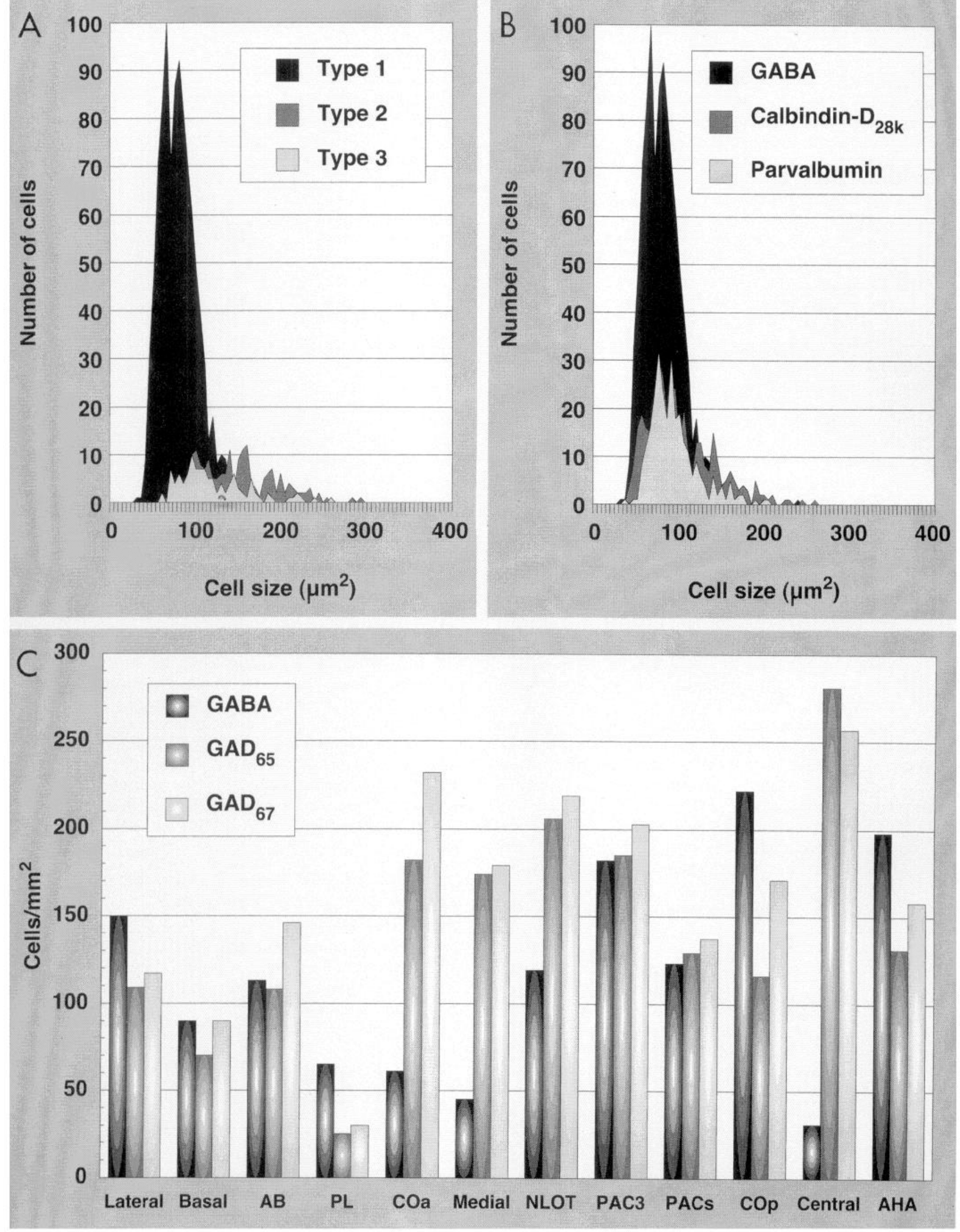
parability of these preparations, we nonetheless found that the mean size of type 1 cells was fairly similar in the GABA-ir and parvalbumin-positive cell populations (Table 2); the calbindin$\mathrm{D}_{28 \mathrm{k}}$ cells appeared to be somewhat larger. The same similarity of sizes is true for the other cell types. Thus, it would appear that the size distributions of the three different populations of cells are largely overlapping.

Perhaps more important than similarities in cross-sectional area are comparisons of densities for cells labeled for the three GABA-related markers (Table 2). It should be borne in mind that rather limited quantitative measures were taken of the density distribution of these cell types. Nonetheless, it appeared that in the lateral nucleus, the density of GABA-ir cells (148/ $\mathrm{mm}^{2}$ ) was substantially higher than the density of parvalbuminir $\left(56 / \mathrm{mm}^{2}\right)$ or calbindin- $\mathrm{D}_{28 \mathrm{k}}-\mathrm{ir}\left(57 / \mathrm{mm}^{2}\right)$ cells. This would suggest that even if there was virtually no colocalization of the two calcium-binding proteins, there would still be a sizable population of GABAergic neurons that would contain neither parvalbumin nor calbindin- $\mathrm{D}_{28 \mathrm{k}}$. This result fits well with studies conducted in other brain regions (Katsumaru et al., 1988; Nitsch et al., 1990; Gulyas et al., 1991; Nitsch and Leranth, 1991) that indicate that there is a separate population of GABAergic neurons that contain one or more peptides but not the calciumbinding proteins.

Finally, in Figure 12 we demonstrate similarities in the somal and dendritic features of the three cell types in the GABA, parvalbumin, or calbindin- $D_{28 \mathrm{k}}$ preparations. Perhaps the clearest morphological difference that we observed was in the populations of type 3 cells (Fig. 12C,F,I). Parvalbumin-ir type 3 neurons typically had a shorter primary dendrite than the GABAir and calbindin- $\mathrm{D}_{28 \mathrm{k}}-\mathrm{ir}$ neurons.

\section{Discussion}

We have carried out immunohistochemical and in situ hybridization studies of the distribution of GABAergic neurons in the macaque monkey amygdaloid complex. GABAergic neurons were visualized in the amygdala both immunohistochemically, using antibodies directed against GABA, and with mRNA probes for $\mathrm{GAD}_{65}$ or $\mathrm{GAD}_{67}$. GABAergic neurons were distributed throughout the amygdaloid complex and accounted for approximately $20 \%$ of the neuronal population, at least in the lateral nucleus. In some regions, such as the intercalated nuclei, virtually all of the resident neurons appeared to be GABAergic. The GABAergic neurons were heterogeneous in size and shape, and three distinct types of GABA-positive cells were identified. In general, the density and distribution of GABA-ir neurons corresponded closely to the in situ labeling patterns. Only in the central, medial, and anterior cortical nuclei was there a disparity; the in situ probes labeled far greater numbers of cells than were identified immunohistochemically. GABA-ir fibers and terminals were also observed throughout the amygdala and were particularly prominent in the central, medial, anterior cortical, and intercalated nuclei. Terminal labeling often took the form of pericellular baskets though other profiles, such as presumed peridendritic terminal arrays ("woolly fibers") were also observed.
Comparison of the distribution of $G A B A$-ir neurons, terminals, and fibers in the monkey amygdaloid complex with previous studies in the rat

The regional distribution of GABA-ir cells in the monkey amygdaloid complex is consistent with earlier work in the rat amygdala (McDonald, 1985; Ottersen et al., 1986; Nitecka and BenAri, 1987; Carlsen, 1988; Nitecka and Frotscher, 1989). These studies have consistently demonstrated that the deep nuclei have a higher density of GABA-ir neurons than the central and medial nuclei. It is also clear from the rat studies that the number of labeled cells observed in the central nucleus is sensitive to whether the axoplasmic transport inhibitor colchicine is used and which particular antibody was employed.

The distribution of GABA-positive neuropil labeling was also comparable in the monkey and rat (McDonald, 1985; Ottersen et al., 1985; Nitecka et al., 1987; Carlsen, 1988). In both species, the neuropil staining was somewhat higher in the central and medial nuclei than in the lateral, basal, and accessory basal nuclei, although these deep amygdaloid nuclei also had a prominent GABA-ir neuropil. In the basal nucleus of the rat, Carlsen (1988) has demonstrated that GAD-ir terminals form symmetrical synapses on the cell bodies of non-GABAergic projection neurons (those that give rise to the amygdalostriatal pathway) as well as on other GAD-ir neurons. We also observed the perisomatic distribution of GABA-ir terminals on the larger presumed projection neurons of the basal nucleus and other deep nuclei. This is suggestive evidence that there is substantial inhibitory control of the amygdaloid efferents (such as those to neocortex and striatum) that originate from these cells. Varicosities were also observed in close association with other GABAir neurons in the deep nuclei of the monkey amygdala but perisomatic baskets were much more difficult to detect. In addition to the conspicuous perisomatic distribution of varicosities, GABA-ir punctate profiles were distributed throughout the neuropil. This may reflect the cxistence of GABAcrgic synapses on distal dendrites as suggested by Carlsen (1988) and Nitecka and Frotscher (1989) in the rat amygdala. Another distinctive terminal specialization observed in the monkey central nucleus consisted of a series of parallel strings of varicosities that appeared to outline dendritic profiles. These closely resembled the so-called "woolly fibers" that were initially described by Mugnaini and Oertel (1985) in the central nucleus of the rat amygdala.

\section{Comparison of present results with previous studies in the primate}

As this article was in the final stages of preparation, a report on the distribution of GABA-ir profiles in the monkey amygdala appeared by McDonald and Augustine (1993). These studies were carried out in Macaca fascicularis monkeys (as in the present study) but used a different, commercially available polyclonal antiserum (Incstar, Inc.) and no in situ hybridization was carried out. The animals in this study were also treated with intraventricular colchicine $24 \mathrm{hr}$ prior to death.

Figure 12. A, The distribution of cross-sectional areas ("cell size") of the three classes of GABA cells are plotted in this panel. $B$, A comparison of the cell sizes of type 1 GABA-ir, calbindin- $D_{28 \mathrm{k}}-\mathrm{ir}$, and parvalbumin-ir neurons. $C$, This histogram compares the density of cells immunoreactive for $\mathrm{GABA}$ with neurons that express either $\mathrm{GAD}_{65}$ mRNA or $\mathrm{GAD}_{67}$ mRNA in different nuclei of the amygdala. Abbreviations are as in Figure 2. 
In most respects, our results and those of $\mathrm{McD}$ onald and Augustine (1993) are comparable. The only area in which there was some difference was in the density and distribution of cells in the central nucleus. McDonald and Augustine (1993) observed a greater number of cells in this region than we did overall and they also observed a greater number in the lateral division than in the medial division. We did not notice a significant difference in the number of labeled cells in the two regions in the GABA-ir preparations and, if anything, there was a slightly higher number of labeled cells in the medial division of the central nucleus in the in situ preparations (see below). Since there were no plots of the density of GABA-ir cells in the central nucleus nor any indication of quantification of cell numbers in this region, it is difficult to compare their results directly with our own. Since our results in other portions of the amygdala are generally consistent with theirs, we attribute their higher number of labeled cells in the central nucleus to the colchicine treatment of their animals rather than to some other factor such as the possible cross-reactivity of their polyclonal antibody. We will discuss this issue further in the next section.

Distribution of $G A D_{6,5}$ and $G A D_{67} m R N A s$ and its relationship to the occurrence of $G A B A$-ir cells in the monkey amygdala

The mammalian brain contains at least two mRNAs for the GABA synthetic enzyme, GAD (Erlander et al., 1991; Kaufman et al., 1991). One encodes a form of GAD with a molecular weight of $65 \mathrm{kDa}$ and another with a molecular weight of 67 $\mathrm{kDa}$. The only available report concerning the expression of GAD in the amygdala is the brief mention of the amygdala in a recently published survey article (Benson et al., 1992). These authors analyzed the distribution of mRNA that encodes the $67 \mathrm{kDa}$ form of GAD in the rat amygdala. Interestingly, they concluded that the level of GAD mRNA was low in all regions of the amygdaloid complex.

Using probes for $\mathrm{GAD}_{65}$ and $\mathrm{GAD}_{67}$, we demonstrated cells that expressed these mRNAs throughout the monkey amygdaloid complex. The number and distribution of in situ labeled neurons closely paralleled the results of the immunohistochemical studies. This replication using independent methods provides substantial assurance that the present data are a reasonably reliable estimate of the relative density of GABAergic neurons in the primate amygdala. A clear difference was observed, however, in the central, medial, and anterior cortical nuclei. Here there was a very high number of neurons expressing GAD mRNAs but very few GABA-ir neurons. In fact, the density of in situ labeled cells in the central nucleus was the highest in the amygdaloid complex whereas it had the lowest density of GABAir neurons (Table 2). These findings are similar to results by Chan-Palay et al. (1988), who demonstrated a higher density of cells labeled by in situ hybridization than by immunohistochemistry for neuropeptide $\mathrm{Y}$ in the human diencephalon.

At this point we return to a discussion of the differences in GABA staining in our study and the recent study of McDonald and Augustine (1993). Previous studies in the rat amygdala have demonstrated that colchicine pretreatment increases the number of GAD-ir cells, especially in the central nucleus (Mugnaini and Oertel, 1985). Presumably the inhibition of axoplasmic transport leads to a buildup of synthesized enzyme in the cell body that allows for identification by the immunohistochemical procedure. Since our in situ results indicate a high level of GAD mRNA in the central nucleus and McDonald and Augustine (1993) observed a higher number of cells in this nucleus follow- ing colchicine administration, it is reasonable to suggest that the lower number of GABA-ir cells that we observed was due to the lack of colchicine treatment in our preparations. This raises the question, however, of why the number of cells we observed in the deep nuclei were comparable with the in situ findings and with the findings of McDonald and Augustine (1993). What is different about the GABAergic neurons in the central nucleus that made them refractory to our immunohistochemical procedures? While we can only speculate at this time, it would be interesting if the lack of staining indicated a much greater rate or distance of axoplasmic transport for neurons in the central nucleus. Perhaps the reason for the increased transport is that many of the central nucleus GABA-ir cells are projection neurons whereas the majority of amygdaloid GABA-ir cells in the deep nuclei are interneurons. Since the in situ preparations indicated that virtually all of the central nucleus neurons contain mRNAs for GAD, one could predict that a sizable component of the far-ranging brainstem projections arising from the central nucleus (Price and Amaral, 1981) uses GABA as a transmitter. The confirmation of this prediction awaits double labeling studies. We should also note that the grain density over labeled cells in our in situ preparations was noticeably lower in the central nucleus than in the deep nuclei. This raises the possibility that the level of GABA synthesis is much lower in central nucleus neurons and this could also contribute to difficulties in visualizing GABAergic neurons with immunohistochemical approaches.

\section{$G A B$ Aergic cells in the monkey amygdala are heterogeneous}

As in the rat, the GABAergic neurons in the monkey amygdala form a heterogeneous population. All are aspiny, but vary in size and shape of soma and in the orientation of their dendritic trees; we have identified three distinct types of GABA-ir neurons based on somal and dendritic morphology. Relative to previous Golgi studies, most of these neurons resemble the Golgi class Il cells described in the rat amygdala by McDonald $(1982,1984)$ and the aspiny Golgi class III neurons, which are devoid of lipofuscin granules in the human amygdala (Braak and Braak, 1983).

One neurochemical index of the heterogeneity of GABAergic neurons is the fact that different subsets appear to colocalize with other neuroactive substances. While we have not yet carried out the necessary double labeling studies, we have carried out independent analyses of the distribution of neurons containing other markers associated with GABAergic neurons such as somatostatin, parvalbumin, and calbindin- $\mathrm{D}_{28 \mathrm{k}}$ (Amaral et al., 1989; Pitkänen and Amaral, 1993a,b). The distribution, morphology, and size of cell types stained for these substances are consistent with the possibility that they are colocalized with GABA. For example, cells resembling the stellate type 1 GABAir cells were also common in the parvalbumin (Pitkänen and Amaral, 1993a) and calbindin- $\mathrm{D}_{28 \mathrm{k}}$ (Pitkänen and Amaral, $1993 \mathrm{~b})$ preparations. It is also likely that there will be some regional selectivity of the colocalization of GABA with other substances. In the central nucleus, for example, we observed relatively few parvalbumin-ir neurons but there were numerous somatostatin-positive cells. In this nucleus, therefore, many of the GABA cells may colocalize with somatostatin rather than parvalbumin. Perhaps the most salient point that can be made at this time is that the number of cells that demonstrate parvalbumin or calbindin- $\mathrm{D}_{28 \mathrm{k}}$ immunoreactivity in the monkey 
amygdala is smaller than the total number of GABAergic neurons. Thus, the monkey amygdala must contain a sizable population of GABA-ir cells that contains neither parvalbumin nor calbindin. These cells may either express another calcium-binding protein or may be members of the cell types observed in other brain regions that colocalize GABA and a peptide transmitter candidate such as somatostatin. That the latter is true derives support from work carried out in the rat. In the rat amygdala, GABA was found to colocalize with somatostatin, neuropeptide $Y$, cholecystokinin, vasoactive intestinal polypeptide, and the calcium-binding proteins parvalbumin and calbindin (McDonald and Pearson, 1989; McDonald and Bainbridge, 1990).

Another signature of GABAergic heterogeneity is differences in synaptic profiles. In the monkey cerebral cortex, one subpopulation of GABAergic cells is formed by so-called chandelier or axoaxonic cells (Hendry et al., 1989). The hallmark of these neurons is the cartridge-like terminal arborization that they form on the initial segments of pyramidal cell axons (DeFelipe et al., 1989). We have recently described parvalbumin-ir cartridges in the magnocellular and intermediate divisions of the basal nucleus and in the ventrolateral division of the lateral nucleus of the monkey amygdala (Pitkänen and Amaral, 1993a). Since parvalbumin colocalizes with GABAergic cells in several brain regions (Hendry et al., 1989) including the rat amygdaloid complex (McDonald and Bainbridge, 1990) and since we also found similarities in the morphology of parvalbumin-ir and GABAir cells, we expected to observe GABA-ir cartridges. We saw very few of these profiles, however. It may bc that our inability to detect cartridges in the GABA immunohistochemical preparations is due, in part, to the obscuring effect of the high density of immunopositive varicosities that form the background neuropil staining. In contrast to chandelier cells, basket cells form pericellular basket-like plexuses of terminals around principal neurons. Many of these basket profiles were observed both in the parvalbumin preparations and in the present GABA material. This suggests that these two markers are colocalized in a population of basket cells. Another distinctive terminal profile was the accumulation of rows of varicosities that appeared to outline dendritic processes. These resembled the so-called "woolly fibers" that are apparent in basal forebrain preparations for the visualization of peptides (Haber and Elde, 1982; Haber and Nauta, 1983). In our previous study of the distribution of somatostatin immunoreactivity in the monkey amygdala (Amaral ct al., 1989) these profiles were most conspicuous in the central nucleus. Interestingly, in the present study similar profiles were seen in the GABA immunohistochemical preparations, again most commonly in the central nucleus.

\section{Electrophysiological indications of heterogeneity in the $G A B A$ ergic system of the amygdala}

We have already discussed the fact that there is heterogeneity in the morphology of GABAergic cells as well as in the patterns of terminal labeling in the monkey amygdala. It also appears that the GABA system has further heterogeneity imposed on it by the different GABA receptor types located in the amygdala, by the presence both of intrinsic and extrinsic GABAergic projections and by the participation of GABAergic cells in feedforward and direct inhibitory circuits.

Recent electrophysiological and pharmacological findings indicate that, in the rat amygdala, as in the hippocampus, GA-
BAergic inhibition is mediated both by $\mathrm{GABA}_{\mathrm{A}}$ and $\mathrm{GABA}_{\mathrm{B}}$ receptors (Nose et al., 1991; Asprodini et al., 1992; Washburn and Moises, 1992a). These studies indicate that when GABA is released at the soma of receptive cells, a GABA-mediated shortlatency hyperpolarization will be obtained. When GABA is released at dendritic sites, in contrast, a long-latency $\mathrm{GABA}_{\mathrm{B}}$ receptor mediated hyperpolarization is observed (Washburn and Moises, 1992a). Interestingly, Sugita et al. (1992) have provided electrophysiological evidence that in the rat lateral nucleus the intra-amygdaloid inputs to $\mathrm{GABA}_{\mathrm{A}}$ and $\mathrm{GABA}_{\mathrm{B}}$ receptors originate from two distinct populations of $\mathrm{GABAergic}$ neurons.

Despite the morphological heterogeneity apparent in immunohistochemical studics of GABAcrgic amygdaloid neurons, only one inhibitory cell type has been characterized electrophysiologically in the rat amygdala (Washburn and Moises, 1992b). These fast-firing neurons demonstrated electrophysiological similarities with inhibitory interneurons (theta cells) found in the rat hippocampus (Schwartzkroin and Mathers, 1978). Germane to the issue of different GABAergic cell types, Washburn and Moises (1992b) demonstrated with Lucifer yellow intracellular filling of the fast-firing cells substantial morphological heterogeneity. This would indicate that future studies may sort out the different classes of amygdaloid GABAergic neurons and define their differential electrophysiological characteristics.

As noted above, there appear to be both extrinsic and intrinsic sources of GABAergic fibers for the amygdala that produce inhibition through feedforward and direct mechanisms. Electrical stimulation of the stria terminalis, for example, results in feedforward inhibition in the basal nucleus of the rat amygdala that has both $\mathrm{GABA}_{\mathrm{A}}$ receptor-mediated fast-IPSP and $\mathrm{GABA}_{\mathrm{B}}$ receptor-mediated slow-IPSP components. Mello et al. (1992a,b) have similarly shown that stimulation of the basal forebrain leads to short-latency IPSPs that presumably are the result of a direct inhibitory projection. Stimulation of the lateral nucleus resulted in both feedforward and direct inhibition of neurons in the basal nucleus (Rainnie et al., 1991). The direct inhibition from the lateral nucleus to the basal nucleus was reported to be $\mathrm{GABA}_{\mathrm{A}}$ receptor mediated. Interestingly, we recently found that about $10 \%$ of the synaptic contacts formed by projections from the lateral to the basal nucleus in the rat were symmetric and thus probably inhibitory (Stefanacci et al., 1992).

Functional considerations. As in most brain regions, the specific functional contribution of GABAergic inhibitory mechanisms in the amygdala is unknown. Two attributes of the amygdala, that is, its involvement in temporal lobe epilepsy and in the evocation of anxiety, are linked to GABAergic function and we will briefly highlight these areas of interest.

Neuronal damage in the amygdaloid complex has been described both in human epileptic patients and in experimental animal models of temporal lobe epilepsy (Margerison and Corsellis, 1966; Schwob et al., 1980; Callahan et al., 1991). It is often thought that cell loss in the hippocampal formation is more closely related to temporal lobe epilepsy, but recently Hudson et al. (1991) and Hudson (1993) described cell loss and gliosis in the amygdala, without hippocampal damage, in a group of epileptic patients who underwent surgery because of the drugrefractory nature of their temporal lobe seizures. A recent magnetic resonance imaging study also detected shrinkage of the amygdala on the side of the primary epileptic focus in patients with temporal lobe epilepsy (Watson et al., 1991). Electrophysiological recordings of the epileptic human amygdala indicate that it is one of the primary brain regions in which epileptic 
seizures and seizure-related behavioral manifestations such as fear originate (Gloor, 1992).

Kindling of the rat amygdala has provided one of the most productive animal models of temporal lobe epilepsy (Goddard et al., 1969). Recently, Callahan et al. (1991) observed 48-62\% decrease in the number of GABA-ir neurons in the contralateral lateral and basal nuclei of amygdala-kindled rats. Moreover, the density of GABA-ir terminals that surrounded unlabeled pyramidal cells in the lateral and basal nuclei was diminished in the contralateral kindled amygdala. Löscher and Schwark (1987) also found decreased synthesis of GABA in the ipsilateral kindled amygdala. If there were a decrease in the number of GABAergic cells or GABA synthesis following amygdala kindling, one might expect reduced stimulus induced inhibition. Interestingly, Rainnie et al. (1991) have demonstrated a kindlinginduced reduction in feedforward GABAergic inhibition in the lateral nucleus of the rat following stimulation of the stria terminalis or direct stimulation of the lateral nucleus. Although there is currently little data indicating that the inhibitory circuitry of the human amygdala is disrupted in temporal lobe epilepsy, data originating from these and other animal studies indicate that this might be a profitable area of future analysis. The neuroanatomical descriptions in this article of the distribution of GABAergic cells in the monkey amygdaloid complex provide a useful starting point for similar analyses in the normal and pathological human brain.

As noted above, the GABAergic system of the amygdala and its relationship to the $\mathrm{GABA}_{A}$ /benzodiazepine receptor complex may play a pivotal role in several forms of affective disorder. Recently, Drevets et al. (1992), using positron emission tomography, reported increased cerebral blood flow in the left amygdala in depressive patients. It has been known for 30 years that the benzodiazepines are therapeutically effective in certain forms of anxiety (see Green, 1991). The clinical symptomatology of the major categories of anxiety disorder, such as panic attack, phobias, obsessive-compulsive syndromes, and generalized anxiety, include heightened levels of autonomic arousal and subjective feeling of fear (Grcen, 1991). Intcrestingly, the amygdaloid complex has one of the highest brain concentrations of benzodiazepine receptors. It would be of interest to determine, therefore, whether alterations of GABAergic function at the $\mathrm{GABA}_{\mathrm{A}}$ /benzodiazepine receptor in the amygdala might be responsible, in part, for the emergence of anxiety disorders. In animals, the amygdaloid complex has clearly been shown to be a critical link in emotional behavior such as in the development of classical fear conditioning (Le Doux, 1992) and fear-potentiated startle reaction (Davis, 1992).

In addition to the cognitive consequences of affective disorders, alterations in a variety of bodily functions are also associated with emotional states. Given the role of the amygdala in mediating various species-specific behaviors, it is not surprising that blocking GABAergic function by intra-amygdaloid infusion of GABA antagonists results in profound alterations in heart rate and blood pressure control (Sanders and Sekhar, 1991), feeding behavior (Minano et al., 1992), and reproductive functions (Wong and Moss, 1992). One theoretical implication of the heterogeneity of GABA systems in the amygdaloid complex is that there are different functional subdivisions of the inhibitory network. This raises the prospect that selective enhancement of the $\mathrm{GABA}_{\mathrm{A}}$ /benzodiazepine receptor, for example, might lead to reduction of anxiety without concomitant alterations in autonomic or regulatory behaviors. The feasibility of this ap- proach awaits further analyses of the regional and subcellular distribution of GABA-associated receptors.

\section{References}

Aggleton JP, Passingham RE (1981) Syndrome produced by lesions of the amygdala in monkeys (Macaca mulatta). J Comp Physiol Psychol 95:961-977.

Amaral DG, Bassett JL (1989) Cholinergic innervation of the monkey amygdala: an immunohistochemical analysis with antisera to choline acetyltransferase. J Comp Neurol 281:337-361.

Amaral DG, Avendano C, Benoit R (1989) Distribution of somatostatin-like immunoreactivity in the monkey amygdala. J Comp Neurol 284:294-313.

Amaral DG, Price JL, Pitkänen A, Carmichael T (1992) Anatomical organization of the primate amygdaloid complex. In: The amygdala: neurobiological aspects of emotion, memory, and mental dysfunction (Aggleton JP, ed), pp 1-66. New York: Wiley-Liss.

Asprodini EK, Rainnie DG, Shinnick-Gallagher P (1992) Epileptogenesis reduces the sensitivity of presynaptic $\gamma$-aminobutyric acid B receptors on glutaminergic afferents in the amygdala. J Pharmacol Exp Ther 262:1011-1021.

Ben-Ari Y, Kanazawa I, Zigmond RE (1976) Regional distribution of glutamate decarboxylase and GABA within the amygdaloid complex and stria terminalis system of the rat. J Neurochem 26:1279-1283.

Benson DL, Isackson PJ, Gall CM, Joncs EG (1992) Contrasting patterns in the localization of glutamic acid decarboxylase and $\mathrm{Ca}^{2+}$ calmodulin protein kinase gene expression in the rat central nervous system. Neuroscience 46:825-849.

Berod A, Hartman BK, Pujol FJ (1981) Importance of fixation in immunohistochemistry: use of formaldehyde solutions at variable $\mathrm{pH}$ for the localization of tyrosine hydroxylase. J Histochem Cytochem $29: 844-850$

Braak H, Braak E (1983) Neuronal types in the basolateral amygdaloid nuclei of man. Brain Res Bull 11:349-365.

Bruton CJ (1988) The neuropathology of temporal lobe epilepsy. In: Inst Psych Maudsley Monographs, Vol 31 (Russell G, Marley E, Williams P, eds). Oxford: Oxford UP.

Callahan PM, Paris JM, Cunningham KA, Shinnick-Gallagher P (1991) Decrease of GABA-immunorcactive neurons in the amygdala after electrical kindling in rat. Brain Res 555:335-339.

Carlsen J (1988) Immunocytochemical localization of glutamate decarboxylase in the rat basolateral amygdaloid nucleus, with specia reference to GABAergic innervation of amygdalostriatal projection neurons. J Comp Neurol 273:513-526.

Chan-Palay V, Yasargil G, Hamid Q, Polak JM, Palay SL (1988) Simultaneous demonstrations of neuropeptide $Y$ gene expression and peptide storage in single neurons of the human brain. Proc Natl Acad Sci USA 85:3213-3215.

Davis M (1992) The role of the amygdala in fear and anxiety. Annu Rev Neurosci 15:353-375.

DeFelipe J, Hendry SHC, Jones EG (1989) Visualization of chandelier cell axons by parvalbumin immunoreactivity in monkey cerebral cortex. Proc Natl Acad Sci USA 86:2093-2097.

Drevets WC, Videen TO, Price JL, Preskorn SH, Carmichael ST, Raichle M (1992) A functional anatomical study of unipolar depression. J Neurosci 12:3628-3641.

Erlander MG, Tillakaratne NJK, Feldblum S, Patel N, Tobin AJ (1991) Two genes encode distinct glutamate decarboxylase. Neuron 7:91100 .

Gloor P (1992) Role of amygdala in temporal lobe epilepsy. In: The amygdala: neurobiological aspects of emotion, memory, and mental dysfunction (Aggleton JP, ed), pp 505-538. New York: Wiley-Liss.

Goddard GV, McIntyre DC, Leech CK (1969) A permanent change in brain function resulting from daily electrical stimulation. Exp Neurol 25:295-330.

Green S (1991) Benzodiazepines, putative anxiolytics and animal models of anxiety. Trends Pharmacol Sci 14:101-104.

Gulyas AI, Toth K, Danos P, Freund TF (1991) Subpopulations of GABAergic neurons containing parvalbumin, calbindin D28k, and cholecystokinin in the rat hippocampus. J Comp Neurol 312:371378.

Haber S, Elde R (1982) The distribution of enkephalin immunoreactive fibers and terminals in the monkey central nervous system: an immunohistochemical study. Neuroscience 7:1049-1095. 
Haber S, Nauta JH (1983) Ramifications of the globus pallidus in the rat as indicated by patterns of immunohistochemistry. Neuroscience 9:245-260.

Hendry SHC, Jones EG, Emson PC, Lawson DEM, Heizmann CW, Streit $P$ (1989) Two classes of cortical GABA neurons defined by differential calcium binding protein immunoreactivities. Exp Brain Res 76:467-472.

Hudson LP, Munoz DG, Girvin JP, Miller L (1991) Amygdalar sclerosis: a novel pattern in temporal lobe epilepsy. Soc Neurosci Abstr $17: 1253$.

Hudson LP (1993) Amygdaloid sclerosis in temporal lobe epilepsy. Ann Neurol 33:622-631.

Kamphuis W, Lopes da Silva FH (1990) The kindling model of epilepsy: the role of GABAergic inhibition. Neurosci Res Commun 6:110.

Katsumaru H, Kosaka T, Heizmann CW, Hama K (1988) immunocytochemical study of GABAergic neurons containing the calciumbinding protein parvalbumin in the rat hippocampus. Exp Brain Res 72:347-362.

Kaufman DL, Houser CR, Tobin AJ (1991) Two forms of the $\gamma$-aminobutyric acid synthetic enzyme glutamate decarboxylase have distinct intraneuronal distributions and cofactor interactions. J Neurochem 56:720-723.

Le Doux J (1987) Emotion. In: Handbook of physiology, Sec 1, The nervous system, Vol V, Higher functions of the brain, Pt 1 (Mountcastle V, Plum F, eds), pp 419-459. Bethesda, MD: American Physiological Society.

Le Doux JE (1992) Emotion and the amygdala. In: The amygdala: neurobiological aspects of emotion, memory, and mental dysfunction (Aggleton JP, ed), pp 339-351. New York: Wiley-Liss.

Le Gal La Salle G, Paxinos G, Emson P, Ben-Ari Y (1978) Neurochemical mapping of GABAergic systems in the amygdaloid complex and the bed nucleus of the stria terminalis. Brain Res 155:397-403.

Lewis DA, Campbell MJ, Morrison JH (1986) An immunohistochemical characterization of somatostatin-28 and somatostatin 28 in monkey prefrontal cortex. J Comp Neurol 248:1-18.

Löscher, W, Schwark WS (1987) Further evidence for abnormal GABAergic circuits in amygdala-kindled rats. Brain Res 420:385-390.

Marcel D, Weissmann-Nanopoulos D, Mach E, Pujol JF (1986) Benzodiazepine binding sites: localization and characterization in the limbic system of the rat brain. Brain Res Bull 16:573-596.

Margerison JH, Corsellis JAN (1966) Epilepsy and the temporal lobes: a clinical, electroencephalographic and neuropathological study of the brain in epilepsy, with particular reference to temporal lobes. Brain 89:499-530.

McDonald AJ (1982) Neurons of the latcral and basolateral amygdaloid nuclei: a Golgi study in the rat. J Comp Neurol 212:293-312.

McDonald AJ (1984) Neuronal organization of the lateral and basolateral amygdaloid nuclei in the rat. J Comp Neurol 222:589-606.

McDonald AJ (1985) Immunohistochemical identification of $\gamma$-aminobutyric acid-containing neurons in the rat basolateral amygdala. Neurosci Lett 53:203-207.

McDonald AJ, Augustine JR (1993) Localization of GABA-like immunoreactivity in the monkcy amygdala. Neuroscience 52:281-294.

McDonald AJ, Bainbridge KG (1990) Calcium binding protein containing neurons of the basolateral amygdala also exhibit GABA and cytochrome oxidase immunoreactivity. Soc Neurosci Abstr 16:431.

McDonald AJ, Pearson JC (1989) Coexistence of GABA and peptide immunoreactivity in non-pyramidal neurons of the basolateral amygdala. Neurosci Lett 100:53-58.

Mello LEAM, Tan AM, Finch DM (1992a) Convergence of projections from the rat hippocampal formation, medial geniculate and basal forebrain onto single amygdaloid neurons: an in vivo extra- and intracellular electrophysiological study. Brain Res 587:24-40.

Mello LEAM, Tan AM, Finch DM (1992b) GABAergic synaptic transmission in projections from the basal forebrain and hippocampal formation to the amygdala: an in vivo iontophoretic study. Brain Res $587: 41-48$

Minano FJ, Meneres Sancho MS, Sancibrian M, Salinas P, Myers RD (1992) $\mathrm{GABA}_{\mathrm{A}}$ receptors in the amygdala: role in feeding in fasted and satiated rats. Brain Res 586:104-110.

Mugnaini E, Oertel WH (1985) An atlas of the distribution of GABAergic neurons and terminals in the rat CNS as revealed by GAD immunohistochemistry. In: Handbook of chemical neuroanatomy,
Vol 4 (Björklund A, Hökfelt T, eds), pp 436-608. Amsterdam: Elsevier.

Nakamura K, Matsumoto T, Hirano M, Kagoshima H, Kuroki T, Yao H, Uchimura H, Nakahara T (1987) Mass fragmentographic determination of $\gamma$-aminobutyric acid and glutamic acid in discrete amygdaloid nuclei of rat brain. $J$ Neurochem 48:1842-1844.

Niehoff DL, Kuhar MJ (1983) Benzodiazepine receptors: localization in rat amygdala. J Neurosci 3:2091-2097.

Niehoff DL, Whitehouse PJ (1983) Multiple benzodiazepine receptors: autoradiographic localization in normal human amygdala. Brain Res 276:237-245.

Nitecka L, Ben-Ari Y (1987) Distribution of GABA-like immunoreactivity in the rat amygdaloid complex. J Comp Neurol 266:4555.

Nitecka L, Frotscher M (1989) Organization of synaptic interconnections of GABAergic and cholinergic elements in the rat amygdaloid nuclei: single- and double-immunolabeling studies. J Comp Neurol 279:470-488.

Nitsch R, Leranth C (1991) Neuropeptide Y (NPY)-immunoreactive neurons in the primate fascia dentata: occasional coexistence with calcium-binding proteins: a light and electron microscopic study. $J$ Comp Neurol 309:430-444.

Nitsch R, Leranth C, Frotscher M (1990) Most somatostatin-immunoreactive neurons in the rat fascia dentata do not contain the calcium-binding protein parvalbumin. Brain Res 528:327-329.

Nose I, Higashi H, Inokuchi H, Nishi S (1991) Synaptic responses of guinea pig and rat central amygdala neurons in vitro. J Neurophysiol 65:1227-1241.

Ottersen OP, Fischer BO, Rinvik E, Storm-Mathisen J (1986) Putative amino acid transmitters in the amygdala. In: Excitatory amino acids and epilepsy (Schwarcz R, Ben-Ari Y, eds), pp 53-66. New York: Plenum.

Pitkänen A, Amaral DG (1991) Distribution of reduced nicotinamide adenine dinucleotide phosphate diaphorase (NADPH-d) cells and fibers in the monkey amygdaloid complex. I Comp Neurol 313:326348

Pitkänen A, Amaral DG (1993a) Distribution of parvalbumin immunoreactive cells and fibers in the monkey temporal lobe: the amygdaloid complex. J Comp Neurol 331:14-36.

Pitkänen A, Amaral DG (1993b) Distribution of calbindin- $D_{28 k}$ immunoreactive cells and fibers in the monkey temporal lobe: the amygdaloid complex. J Comp Neurol 331:199-224.

Price JL, Amaral DG (1981) An autoradiographic study of the projections of the central nucleus of the monkey amygdala. J Neurosci 11:1242-1259.

Price JL, Russchen FT, Amaral DG (1987) The limbic region. II. The amygdaloid complex. In: Handbook of chemical neuroanatomy, Vol 5 , Integrated systems of the CNS, Pt I (Björklund A, Hökfelt T, Swanson LW, eds), pp 279-388. Amsterdam: Elsevier.

Quinn B, Graybiel AM (1990) A reliable, differentiated silver intensification for DAB immunohistochemistry. J Histochem Cytochem 30:722.

Rainnie DG, Asprodini EK, Shinnick-Gallagher P (1991) Inhibitory transmission in the basolateral amygdala. J Neurophysiol 66:9991009.

Rainnie DG, Asprodini EK, Shinnick-Gallagher P (1992) Kindlinginduced long-lasting changes in synaptic transmission in the basolateral amygdala. J Physiol (Paris) 67:443-454.

Sanders SK, Shekhar A (1991) Blockade of $\mathrm{GABA}_{\mathrm{A}}$ receptors in the region of the anterior hasolateral amygdala of rats elicits increases in heart rate and blood pressure. Brain Res 576:101-110.

Schwartzkroin PA, Mathers LH (1978) Physiological and morphological identification of a nonpyramidal hippocampal ccll type. Brain Res 157:1-10.

Schwob JE, Fuller T, Price JL, Olney JW (1980) Widespread patterns of neuronal damage following systemic or intracerebral injections of kainic acid: a histological study. Neuroscience 5:991-1014.

Stefanacci L, Farb CR, Pitkänen A, Go G, LeDoux JE, Amaral DG (1992) Projections from the lateral nucleus to the basal nucleus of the amygdala: a light and electron microscopic PHA-L study in the rat. J Comp Neurol 323:586-601.

Stroessner HM, Houser CR, Richards JG, Amaral DG (1989) Distribution of benzodiazepine/GABA $\mathrm{G}_{\mathrm{A}}$ receptors in the monkey medial temporal lobe: an immunohistochemical analysis. Soc Neurosci Abstr 15:1154. 
Sugita S, Johnson SW, North RA (1992) Synaptic inputs to GABA and $\mathrm{GABA}_{\mathrm{B}}$ receptors originate from discrete afferent neurons. Neurosci Lett 134:207-211.

Szabat E, Soinila S, Häppölä O, Linnala A, Virtanen I (1992) A new monoclonal antibody against the GABA-protein conjugate shows immunoreactivity in sensory neurons of the rat. Neuroscience 47;409420.

Tranel D, Hyman BT (1990) Neuropsychological correlates of bilateral amygdala damage. Arch Neurol 47:349-355.

Washburn MS, Moises HC (1992a) Inhibitory responses of rat basolateral amygdaloid neurons recorded in vitro. Neuroscience 50:811830.

Washburn MS, Moises IIC (1992b) Electrophysiological and morphological properties of rat basolateral amygdaloid neurons in vitro. J Neurosci 12:4066-4079.

Watson C, Anderman F, Gloor P, Jones-Gotman M, Peters T, Evans A, Olivier A, Leroux G (1991) MRI-based measurement of the amygdala and hippocampus: description of method and normal control data. Epilepsia 32[Suppl 3]:76.

Weiskrantz L (1956) Behavioral changes associated with ablation of the amygdaloid complex in monkeys. J Comp Physiol Psychol 49: 381-391.

Wong M, Moss RL (1992) Modulation of single-unit activity in the rat medial amygdala by neurotransmitters, estrogen priming, and synaptic inputs from the hypothalamus and midbrain. Synapse 10:94 102

Zezula J, Cortes R, Probst A, Palacios JM (1988) Benzodiazepine receptor sites in the human amygdala: autoradiographic mapping. Neuroscience 25:771-795.

Zola-Morgan S, Squire LR, Alvarez-Royo P, Clower R (1991) Independence of memory functions and emotional behavior: separate contributions of the hippocampal formation and the amygdala. Hippocampus 1:207-220. 